Article

\title{
Spatio-Temporal Rainfall Variability and Flood Prognosis Analysis Using Satellite Data over North Bihar during the August 2017 Flood Event
}

\author{
Gaurav Tripathi ${ }^{\circ}$, Bikash Ranjan Parida * ${ }^{-}$and Arvind Chandra Pandey \\ Department of Geoinformatics, School of Natural Resource Management, Central University of Jharkhand, \\ Ranchi 835205, Jharkhand, India; gauravtripathi3135gt@gmail.com (G.T.); arvindchandrap@yahoo.com (A.C.P.) \\ * Correspondence: bikashrp@gmail.com; Tel.: +91-7992257184
}

Received: 24 January 2019; Accepted: 13 May 2019; Published: 17 May 2019

\begin{abstract}
Flooding is one of the most common natural disasters in India. Typically, the Kosi and Gandak river basins are well-known for lingering flood affected basins in North Bihar every year, which lies in the eastern part of India. There were no such comprehensive studies available in North Bihar that discussed flood progression and regression at shorter time-scales like two day intervals. So in this study, we employed high temporal resolution data to capture inundation extent and further, the flood extent has been validated with high spatial resolution data. The specific objective of this study was to analyze the satellite-derived Near Real Time (NRT) MODIS flood product for spatiotemporal mapping of flood progression and regression over the North Bihar. The synthetic aperture RADAR (SAR) data were also used to validate the MODIS NRT Flood data. As a case study, we selected a recent flood event of August-September 2017 and captured the flood inundation spatial extent at two day intervals using the 2 day composite NRT flood data. The flood prognosis analysis has revealed that during the peak flooding period, $12 \%$ to $17 \%$ of the area was inundated and the most adversely affected districts were Darbhanga and Katihar in North Bihar. We estimated that in total nearly $6.5 \%$ area of the North Bihar was submerged. The method applied was simple, but it can still be suitable to be applied by the community involved in flood hazard management, not necessarily experts in hydrological modeling. It can be concluded that the NRT MODIS flood product was beneficial to monitor flood prognosis over a larger geographical area where observational data are limited. Nevertheless, it was noticed that the flood extent area derived from MODIS NRT data has overestimated areal extent, but preserved the spatial pattern of flood. Apparently, the present flood prognosis analysis can be improved by integrating microwave remote sensing data (SAR) and hydrological models.
\end{abstract}

Keywords: flood progression and regression; satellite-derived rainfall; MODIS NRT Flood product; Kosi and Gandak River; water levels

\section{Introduction}

Flooding is one of the most devastating and recurring events in the Indian subcontinent because of its geographical and riverine structure, which makes various parts of the nation prone to floods. The causative factors of frequent floods in India are intense rainfall, dam breach, unplanned urbanization, and land use/land cover (LU/LC) changes, that typically leads to the loss of lives and properties. As flood events have been increasing over the last three decades [1], the development of flood mapping using satellite data and application of flood inundation models become crucial to monitor and assess flood impact. Mostly in densely populated countries like India, an effective flood monitoring and forecasting system has been lacking due to inadequate resources [2]. Satellite remote sensing data can 
be an alternative to provide information on flood progression over larger areas since this is impractical through in situ observation.

Satellite data can map the extent of flooding over large geographical areas and thereby extremely useful where in-situ data are limited. Over the last few decades, the quantity and quality of satellite products that are available to various stakeholders during a flood event has further improved flood monitoring and mapping. The advances in satellite data in respect of high spatial and temporal resolutions have led to the development of near real-time flood mapping algorithms [3,4]. This provides vital information during an emergency as satellite-derived information typically used to calibrate and validate hydrodynamic models, such as, Hydrologic Engineering Center-River Analysis System (HEC-RAS 2D (Two dimensional), MIKE3 3D (Three dimensional), TUFLOW (3D), etc.) [5-8]. Satellite data have been used to improve the predictive accuracy and have subsequently, increased the stakeholder's understanding of flood dynamics and flood forecasting $[9,10]$.

To monitor surface water dynamics, both optical and synthetic aperture radar (SAR) have been widely used in the literature. Optical satellite data are passive sensors and during flood events, these data have limitations for mapping flooding as cloud cover is unable to be penetrated [11]. By contrast, SAR systems have an advantage over optical sensors by enabling collection of data with cloud cover $[12,13]$. The Land/Water interface can be easily discriminated with SAR and further, it helps to delineate flood extent and management. In this regard, studies have utilized SAR data to map the temporal extent of floods [14-17]. For instance, RADARSAT-1 data were used to map the spatiotemporal dynamics of the flood inundation extent in 2004 for the Kosi river basin [17]. The only drawback of the SAR sensor is their temporal resolution and as a result, satellite images at frequent intervals are not available during the flooding event.

Despite some limitation in passive sensors, this sensor satellite data has been used widely for flood inundation extent mapping, monitoring, and flood risk management. Further, flood inundation extent derived through satellite images acts as an important input to map the progression and regression of flooding. Using various sources of optical sensor satellite data, several studies have investigated the recurring flood events in North Bihar along the Kosi river to map flood hazards, vulnerability, and risks during flood events from 2000 to 2008 [18-20]. The seasonal and permanent waterlogging zones were mapped and risk zones identified using the IRS AWIFS (Indian Remote Sensing Advanced Wide Imaging Field Sensor) and Landsat (MSS: Multi Spectral Sensor, ETM+: Enhance Thematic Mapper) satellite data with spatial resolution of 30 to $60 \mathrm{~m}$ [18]. The RADARSAT images were employed by Singh et al. [19] for flood pixels extraction using image segmentation over the Kosi basin. Analytical Hierarchy Process and Geographic Information System techniques have been also effectively employed to map flood inundation in 2003 and 2006 and further, they identified flood risk zones in the Kosi river basin [21]. The Moderate Resolution Imaging Spectrometer (MODIS)-derived coarser spatial resolution data was also used extensively for flood water extent mapping over North Bihar region for some major flooding events during 1975, 2001, and 2008 [18]. Besides satellite data, a number of literatures suggested that various empirical, hydrodynamic, and 3D flood models could be considered as an effective tool for flood inundation as well as depth mapping [5,6,22]. Studies have also attempted to apply Artificial Neural Networks technique and self-organizing Kohonen's maps for delineating flood inundated areas in various countries [23,24]. Flood extent information is useful further for damage assessment and risk management, and can assist to rescuers during flood events.

Precipitation is a crucial meteorological input of a hydrologic model for flood extent mapping, which can be obtained through satellite data at relatively high spatiotemporal resolution. In this regard, several studies have discussed flood forecasting using satellite precipitation products and hydrodynamic models. In particular, satellite precipitation products are very useful because of their larger area coverage during rainstorms. Several rainfall-runoff model were integrated with satellite precipitation products to forecast floods and their severity $[25,26]$. The Tropical Rainfall Measuring Mission (TRMM)-based Multi-satellite Precipitation Analysis (TMPA) products [27] have been effectively used in many hydrological models including extreme flood event disaster studies [28-31]. In fact, various 
hydrologic models and flood analysis have been evaluated using satellite-based precipitation products and it has been suggested that these data are extremely useful for flood progression analysis at local and regional scales $[28,32,33]$.

In particular, over the North Bihar region, previous studies analyzed individual flood events, namely, 2008, 2010, 2013 using multitemporal optical and SAR satellite data along with the hydrological models. However, there were no such comprehensive studies available that discussed flood progression at shorter time-scales like a two day intervals. So in this study, we employed high temporal resolution data (MODIS) to capture flooding conditions and further, flooding extents validated with high spatial resolution data (SAR). The major challenge is availability of optical data during flooding at 2 day intervals owing to cloud contamination. But in case of SAR data, lower temporal resolution hinders the study. So in this study, we aimed to analyze the flood event of 2017 as a case study over North Bihar, which occurred during August and September months by integrating both high temporal and spatial resolution data. The prime objectives of this comprehensive study were to map the flood inundation extent during progression and regression periods with spatiotemporal changes of precipitation, and to characterize the rainfall induced runoff and water flow pattern at various gauge stations of North Bihar during the 2017 flood event. The case study of the 2017 flood event was intended to provide an insight into the flood extent change over a 2-day period using MODIS-based NRT flood product, providing information on flood prognosis, as well as highlighting the usefulness of satellite-derived precipitation products.

\section{Study Area}

The study area comprises 19 districts of North Bihar in India. Geographically, it extends between $82.3^{\circ} \mathrm{E}$ to $88.9^{\circ} \mathrm{E}$ longitude and $24.8^{\circ} \mathrm{N}$ to $29.3^{\circ} \mathrm{N}$ latitude. The Upper Ganga basin comprises several rivers and its basin inside the North Bihar boundary. Major subbasins of the Upper Ganga basin are the Kosi river basin (45,903 sq.km) and the Burhi Gandak river basin (87,165 sq.km). Several tributaries/dhars are present there, namely, Gandak, Bagmati, Adhwara Group, Kamla Balan, Bhutahi Balan river, Dhemama dhar, etc. and these tributaries drain water to the major rivers of the basin. The area of North Bihar districts under Kosi and Burhi-Gandak river's catchment is 45,903 sq.km (Figure 1). But, the area of the Kosi river catchment inside North Bihar is 19,809 sq.km.

The Kosi river originates from the Himalayas at an altitude of $7000 \mathrm{~m}$, having three major tributaries, namely, the Sun Kosi, Arun, and Tamur. Each one of them contributes a high amount of water to the main channel of the Kosi river. Nearly $80 \%$ of the Kosi catchment is situated in Nepal and Tibet and the remaining portion lies inside the Bihar state (India). Baghmati and Kamla are the main rivers of the Kosi and Gandak river catchment that also forms a subbasin in the Kosi and Gandak basin.

There are many seasonal water channels presents inside the Kosi Gandak boundary called 'dhars', which are activated only during monsoon season (July-October) and contribute a large amount of water to the main stream that makes it more vulnerable. The districts of North Bihar, such as, Saharsa, Darbhanga, Khagaria, Bhagalpur, Muzzafarpur, Araria, Kishanganj are situated along the Kosi and Burhi Gandak river. Thereby, flooding occurred every year and caused inundation over larger areas of North Bihar. Because of recurring flood occurrence over the Kosi river basin, the Kosi river is known as the "Sorrow of Bihar". Floods in Bihar are generally caused by the breach of embankment along the Kosi river owing to intense rainfall during the monsoon season. A number of remedial measures have been implemented by the government of Bihar (India) and Nepal to restrict frequent flooding and to protect the lowland areas of North Bihar and Nepal [21]. The remedial measures, such as, major and minor embankments, water channels, storage ponds, etc. have been constructed to restrict and control the heavy flow of water during floods. Despite these flood protective measures, the Kosi river's flood occurs almost every year and causes severe damage to infrastructure as well as human lives. 


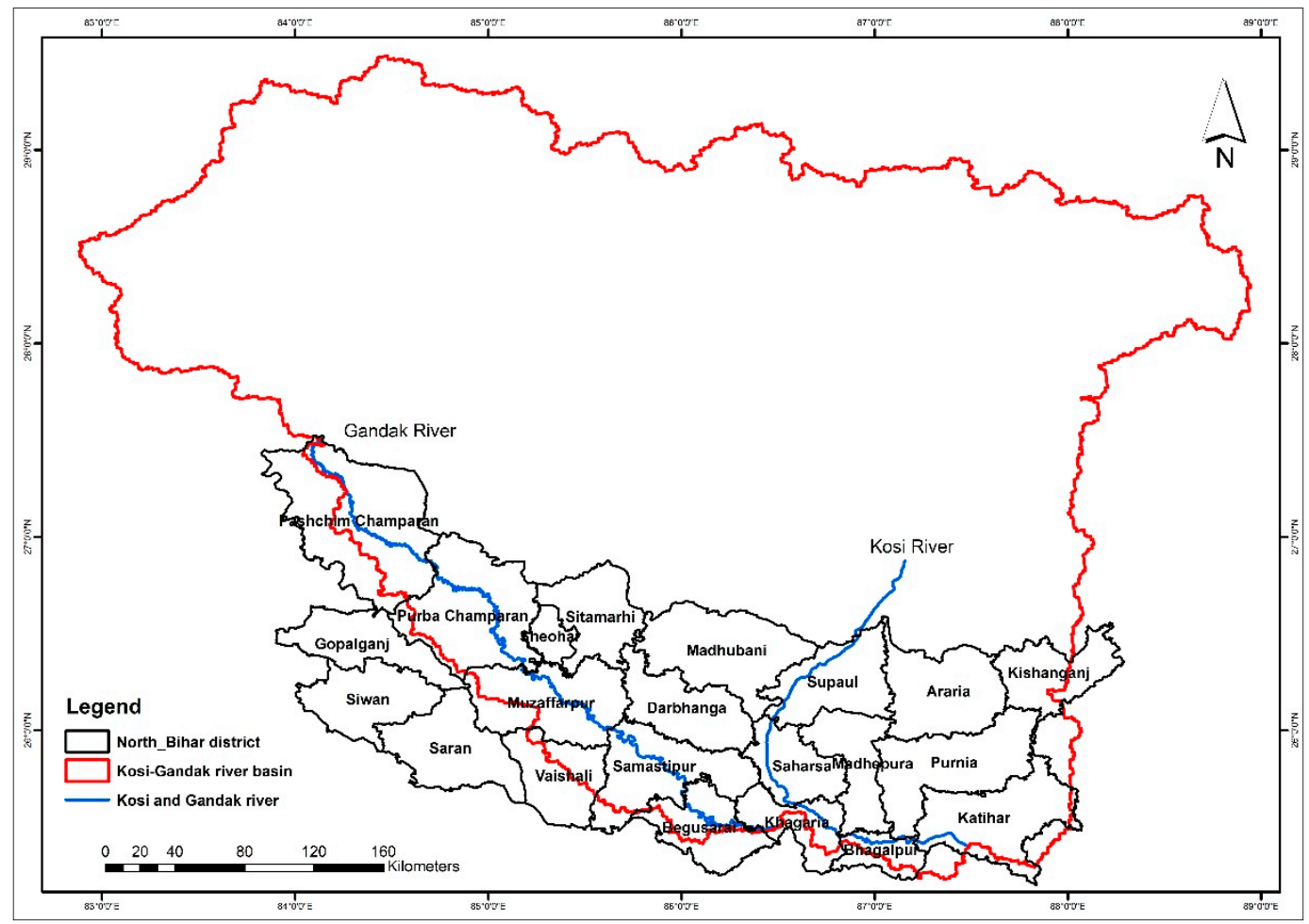

Figure 1. Location map of North Bihar region and Kosi Gandak river basin (red color boundary). The basin is situated in the northern part of India, Nepal, and Tibet. The major/minor tributaries of rivers Ganga, Kosi and Gandak have been overlaid over the 19 districts of the North Bihar region.

According to Flood Management Information System Cell (FMISC), flood can be classified into four classes, such as, Class 1 (Flash flood), Class 2 (River flood), Class 3 (Drainage congestion in river confluence), Class 4 (Permanent waterlogging) [34]. In particular, the Kosi river's characteristics and flood controlling parameters have been discussed in [35,36]. Typically, intense rainfall during the monsoon season generates higher runoff and subsequently, it drains towards the lower catchment areas of the Kosi basin. Consequently, it makes the low lying areas of north Bihar highly prone to flooding and waterlogging (Figure 1). The historical hydrographic data showed that flood events were observed in 1987, 1998, 2000, 2001, 2003, 2004, 2008, 2010, 2013, 2017, and 2018. The flood event in 2013 in Bihar affected $>5.9$ million peoples across 20 districts of Bihar. The flood incurred in 2017 was one of the major flood events that affected 19 districts of North Bihar. The flood event 2017 was the result of a sudden increase in water discharge due to torrential rain in the foothill of the Himalayas near Nepal and adjoining areas. The tributaries of these rivers were flooded between the 12th and the 30th August 2017. As per the National Disaster Management Authority (NDMA), Bihar is one of India's worst affected states owing to recurring floods [37]. It was reported that $\sim 16.5 \%$ area of Bihar was prone to flooding that adversely affected $\sim 22.1 \%$ of the population. Over North Bihar region, it was reported that $\sim 76 \%$ of the population were living under floods [38]. Typically, floods in Bihar are a recurring disaster event and are observed on an annual basis that destroys thousands of humans live including live stocks and other assets.

\section{Materials and Methods}

In this study, satellite data were used to demarcate the flood extent areas over the North Bihar region. The detailed description of satellite data is provided in Table 1. To map flood progression, we used the time-series MODIS flood data during the period of August and September, 2017. Sentinel-1 (SAR) and Landsat-8 OLI (Operational Land Imager) data have been also used for the flood extent mapping and for validation against the MODIS NRT flood product. To link rainfall with flood 
inundation pattern, we used daily satellite-derived precipitation estimates from TMPA (TRMM Multi Precipitation Analysis). The observed rainfall data by Indian Meteorological Department (IMD) were also used for comparisons of rainfall with satellite-derived precipitation estimates. Further, the hydrographs as obtained from the Central Water Commission (CWC) during the flood event (August-September, 2017) were used for rainfall-runoff assessment which could be indicative of flood progression and regression during whole flooding period.

Table 1. Characteristics of the satellite and secondary data used in this study. The satellite data were acquired in the month of August and September, 2017. The abbreviations used are: USGS (United States Geological Survey), NRT (Near Real Time), ASF (Alaska Satellite Facility), IMD (Indian Meteorological Department), CWC (Central Water Commission) and GIOVANNI (Geospatial Interactive Online Visualization ANd aNalysis Infrastructure).

\begin{tabular}{cccccc}
\hline Name of Dataset & $\begin{array}{c}\text { Temporal } \\
\text { Resolution }\end{array}$ & Spatial Resolution & Acquisition Date & Source \\
\hline Landsat- 8 (OLI) & 16 days & $30 \mathrm{~m}$ & 12, 21, 26, 28 Apr, 2017 & USGS \\
MODIS Flood data & $24 \mathrm{~h}$ & $250 \mathrm{~m}$ & August-September, 2017 & NRT Flood product \\
Sentinel-1A & 12 days & $10 \mathrm{~m}$ & 23rd August, 2017 & ASF \\
TMPA (3B42RT) & $3 \mathrm{~h}$ & $0.25^{\circ} \times 0.25^{\circ}$ & August-September, 2017 & GIOVANNI \\
ASTER GDEMV2.0 & 16 days & 1 arc second $(30 \mathrm{~m})$ & 17th October 2011 & USGS \\
Rainfall (station-wise) & $12 \mathrm{~h}$ & - & August and September, 2017 & IMD \\
Hydrographs & $3 \mathrm{~h}$ & - & Daily (station-wise) & CWC \\
\hline
\end{tabular}

\subsection{MODIS Flood Data}

The Moderate resolution imaging spectro-radiometer (MODIS) is a multispectral imaging system on board National Aeronautics and Space Administration's (NASA's) Terra and Aqua satellites. It operates using 36 spectral bands and provides twice daily global coverage at $250 \mathrm{~m}$ spatial resolution. These data were available in Hierarchical Data Format (HDF) and distributed by the NASA Land Processes Distributed Active Archive Centre (LP DAAC).

The Near Real Time (NRT) Flood products are distributed through the Global Flood monitoring Centre developed by the Dartmouth Flood Observatory (DFO) [39]. These data are available in the raster format with two different classes, namely, the MFW (MODIS Flood Water) and MSW (MODIS Surface Water). The MFW provides the flooded water pixels, whereas the MSW provides the regular surface water bodies like ponds, rivers, small water pockets etc. The water pixels were detected by an algorithm in which the ratio of MODIS reflectance Band of 1 (red) and 2 (infrared) were used, and a further threshold of Band 7 (shortwave infrared) was used to identify water pixels. The Landsat satellite data were also used to validate the evaluation of flood water pixels with MODIS (250 m) reflectance data. Flooded pixels are used to be detected as a composite product window of 2 days, and further converted into 3 day and 14 day composite products. Two (or more) observations are required because cloud shadow can appear quite spectrally similar to water. In cases where cloud shadow occurs in the same spot in multiple observations, the product may incorrectly flag as water. The detected water is compared to a reference water layer that shows "normal" water extent, and any pixels found outside the normal water extent are marked as flood [39]. In the MFW product, four classes are represented as 0 (no data), 1 (no water detected), 2 (water but not flood), and 3 (water detected and likely flood). The classes 0 to 2 were grouped into non-flooded and the class 3 as flooded (Figure 2). The water pixels are identified by a 4 image and 6 image set from Terra and Aqua, respectively. This helps to remove cloud shadow noise, true flood near clouds, and also increases the latency of the product [39].

\subsection{Landsat-8 (OLI) Sensor Data}

The Landsat-8 series data were obtained from the United States Geological Survey (USGS)-Earth Explorer and are available from 2012. Especially, Operational Land Imager (OLI) sensors data are available at $30 \mathrm{~m}$ spatial resolution. The OLI sensor has nine spectral bands covering visible to near 
infrared regions. Here, we acquired the OLI sensor data during April, 2017 that corresponds to the pre-flood condition. The major rivers and basin boundaries were demarcated based on digitization. A drainage map was generated using digitization of satellite data as well as a survey of Indian topographical sheets (Figure 2).

\subsection{Sentinel-1 Satellite Data}

The Sentinel-1 SAR satellite mission was conducted by European Space Agency (ESA) and composed of two radar satellites. This provides C-band images in both single and dual polarization within 12 days of repeat cycle. The SAR data of 23rd August, 2017 was obtained free of cost from Alaska Satellite Facility (ASF).

\subsection{TMPA-Based 3B42RT Precipitation Product}

The TRMM Multi-Satellite Precipitation Analysis (TMPA) based 3B42-RT product provides a real-time measurement of rainfall data using precipitation radar (PR) sensor at $0.25^{\circ} \times 0.25^{\circ}$ spatial resolution. The PR sensor has operated at $13.8 \mathrm{GHz}$ since 1997 [27]. This daily accumulated rainfall product ( $\mathrm{mm} /$ day) was derived from the originally available 3-hourly TRMM-3B42 product. These data were obtained data from TOVAS (TRMM Online Visualization and Analysis System), maintained by the Data and Information Services Centre of Goddard Earth Sciences of NASA.

\subsection{Station-Wise Indian Meteorological Department (IMD) Rainfall Data}

The Indian Meteorological department (IMD) provides rainfall data station-wise all over the country using 1289 rain gauge stations. In the state of Bihar, there were 200 rain gauge stations available to provide rainfall at a daily basis. IMD has installed automatic rain gauge stations at different districts of North Bihar, such as, Sitamarhi, Muzzafarpur, Supaul, Bhagalpur, Madhepura, Purnea, Samastipur, and Darbhanga etc. and these data have been used for various hydrometeorological applications $[40,41]$.

\subsection{Hydrograph Data of Central Water Commission (CWC)}

The CWC was established by the Ministry of Water Resources, River development and Ganga rejuvenation, Government of India in 1952. Its hydro-meteorological sites are responsible for providing hydrological, meteorological and water quality parameters for the whole Indian region. We obtained hydrographs from CWC to analyze different water level during flood periods in 2017. This provides crucial information of namely, warning level (WL) and danger level (DL), and highest flood level (HFL) with current flooding level particularly at every rain gauge station that helps in runoff generation. We used the water level data derived from the product of gauge stations, such as Muzzafarpur, Ahirwalia, and Samastipur etc. which were located across the Kosi Gandak river basin regions of North Bihar. These data were available at the CWC portal.

\subsection{Digital Elevation Model Data (ASTERGDEM V2)}

The ASTER (GDEM V2 version) Digital Elevation Model (DEM) data are available at $30 \mathrm{~m}$ spatial resolution and these datasets can be accessed from the USGS Earth explorer. The DEM has been used to demarcate the flow direction, drainage networks, and for demarcating the basin map of North Bihar. We used ASTER-based DEM because it is having relatively finer spatial resolution than the Shuttle Radar Topography Mission (SRTM) DEM (90 m). In this study, the ASTER based DEM is used to derive drainage patterns and flow directions over the catchment area because of relatively higher spatial resolution than the SRTM. 


\subsection{Survey of India (SOI) Toposheet}

The toposheets at 1:50,000 scale were obtained from the survey of India (SOI) located at Dehradun, India. These maps were used to draw the districts boundary, basins, major minor river streams, and transportation networks of the study area.

\subsection{Methods}

The MODIS-based NRT flood product (raster data) was used to create flood maps, wherein four classes are represented as 0 (no data), 1 (no water detected), 2 (water but not flood), and 3 (water detected and likely flood). Flood inundation maps were generated especially from class 3 . The statistics of this class was computed to quantify areas under flood.

To assess the spatiotemporal variability of rainfall, the daily TMPA dataset was converted to gridded XYZ format. The conversion resulted in point-wise rainfall data in ASCII format. To get continuous rainfall data over the study area, the recorded rainfall values for every point were interpolated in the spatial environment using the Inverse distance weighting (IDW) method in ArcGIS software. The IDW is a type of deterministic method for multivariate interpolation with known scattered set of points [42]. The assigned values to unknown points are calculated with a weighted average of the values available at various known points [43]. The Inverse Distance Weighting interpolator assumes that each input point has a local influence that diminishes with distance. It weights the points closer to the processing cell greater than those further away. A specified number of points, or all points within a specified radius can be used to determine the output value of each location. In several studies, they have used IDW technique to interpolate point values to get continuous raster data over the area which gave better results [44].

Rainfall estimates of TMPA and IMD were compared to understand the differences in magnitudes of rainfall. The CWC hydrographs were used to the fetch water levels at various gauge stations at an interval of every $12 \mathrm{~h}$ and compared with historical data to investigate the inundation extent over the Kosi Gandak river basin. The district shape files of North Bihar were generated using SOI toposheets. This helped to locate the districts that received maximum rainfall over the complete rainfall period. The Landsat- 8 satellite images were also used to demarcate catchment boundary, major and minor river channels along with the help of toposheet (Figure 1). The basin map, flow direction map, and drainage map were derived from DEM that helped to calculate surface runoff and water accumulation zones. The flow direction was estimated based on the direction of slope with respect to each neighboring cell. When the direction of steepest descent was found, the output cell was coded with the value representing that direction. If all neighbors are higher than the processing cell, it is considered as noise and is filled using the lowest value of its neighbors $[45,46]$. The eight directions pour point model is often used to determine the flow direction of water [45]. Slope is the ultimate factor through which water flows in one or more of its eight adjacent cells. The values 1, 2, 4, 8, 16, 32, and 64 are assigned according to the flow direction [47]. The detailed methodology adopted is shown in Figure 2.

Sentinel-1A SAR satellite data was used to validate flooding extent of MODIS NRT Flood data. Sentinel-1A SAR data was pre-processed and flood pixels were extracted using binarization, a method of thresholding as described in [14]. The threshold value of $-25 \mathrm{~dB}$ was applied to extract flood pixels. Other classification methods, such as, Random Forest Classifier (RFC) and Support Vector Machine (SVM) can be used to extract flooded pixels. As per the literature, backscatter binarization analysis was the most suitable method for flood pixels extraction [13-16]. Notably, satellite data are widely used to demarcate flooding using digital image processing techniques, such as, image classification, image segmentation, and image binarization. These data are also used as an input parameters for various hydrological models for flood inundation mapping. Over the North Bihar, we used image classification (MODIS NRT data) and binarization (Sentinel-1A SAR data) methods for flood pixels extraction. However, to demarcate flooding conditions, there are other approaches, namely, rainfall-runoff modelling, hydrological models, and machine learning techniques [48-51]. The field survey approach can be employed for mapping flood, but are very cumbersome. 


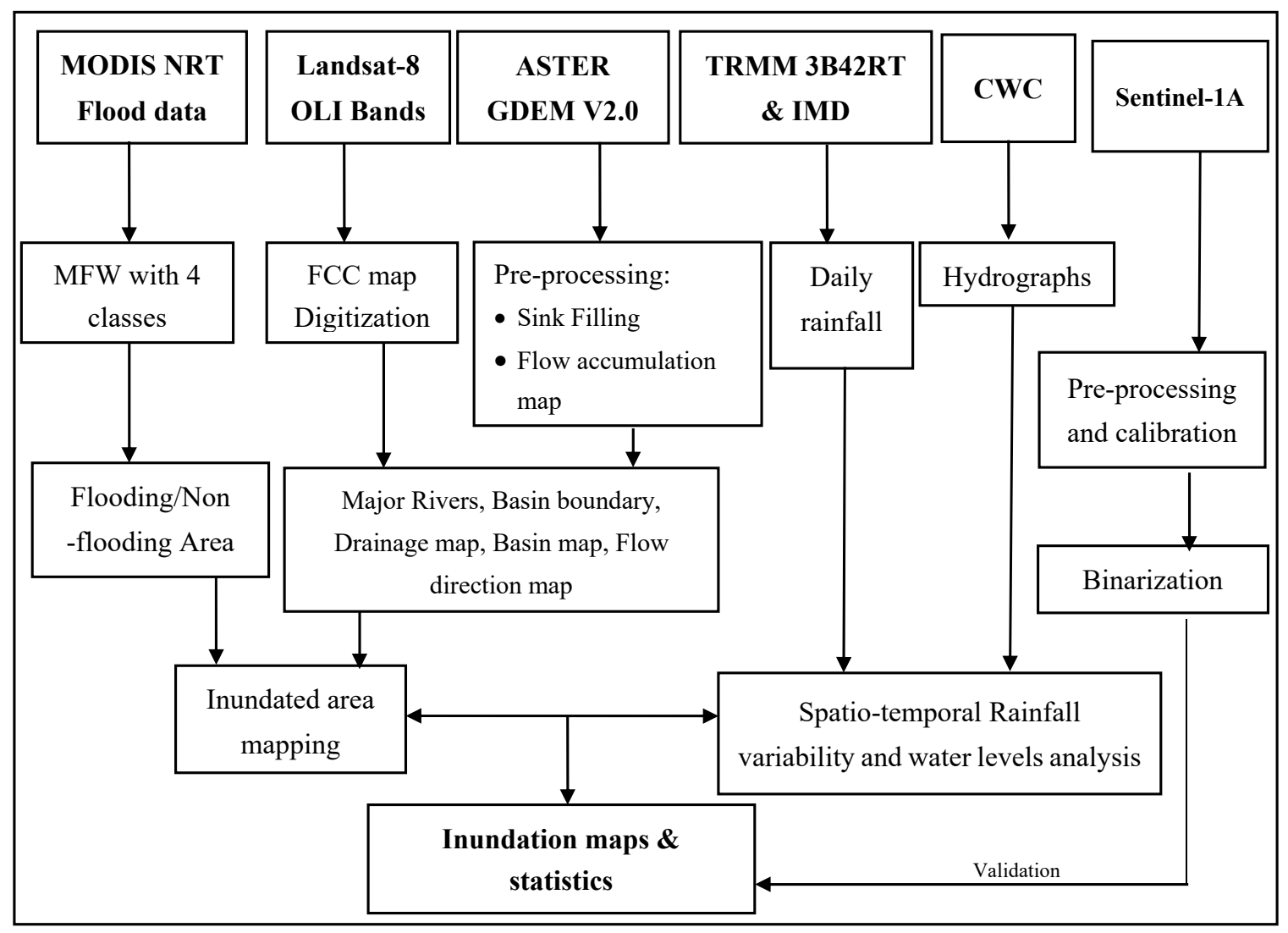

Figure 2. The detailed methodology adopted for this study.

\section{Results}

\subsection{Rainfall Variability over the Kosi and Gandak Basin during August-September, 2017}

The accumulated rainfall maps of TMPA at every 3 day interval during the flood event in August, 2017 over the North Bihar are shown (Figure 3) to assess the spatio temporal rainfall variability across the Kosi and Gandak basin's catchment. The accumulated rainfall maps were presented to identify the districts of North Bihar, which received intense rainfall. These results showed that the accumulated rainfall during the period of 10-12th August was up to $324 \mathrm{~mm}$ and the mean rainfall was estimated as $107 \mathrm{~mm}$. Notably, we found that during these three days in August, 2017 maximum rainfall was received over North Bihar and Nepal. All these regions are located the Kosi Gandak river basin, which subsequently led to flood like conditions over downstream areas. The precipitated water travelled through a gentle slope from the upper catchment (Tibetan Plateau and Nepal) to the lower catchment areas of North Bihar. During 13-15th August, the accumulated rainfall received was less than the previous dates and during this period, the maximum and mean rainfall was observed as 253 and $85 \mathrm{~mm}$, respectively. During the period of 16-21st August, the rainfall was further reduced and concentrated over the north west part of the catchment and the mean rainfall was estimated as $52 \mathrm{~mm}$. During 19-21st and 22-24th August, rainfall again increased relatively to the previous dates and the mean rainfall was estimated at 114 and $148 \mathrm{~mm}$, respectively. The rainfall was concentrated mostly over the south east and north west part of the basin during 22-24th August and 19-21st August as displayed in Figure 3. The rainfall further increased up to 217mm during 25-27th August, especially in the lower eastern parts of the catchment. During this period, the eastern part of the catchment exhibited a substantial amount of rainfall and the maximum was estimated as $395 \mathrm{~mm}$, while the mean was $79 \mathrm{~mm}$. For the next two days 28-29th August, the rainfall diminished to $92 \mathrm{~mm}$. 


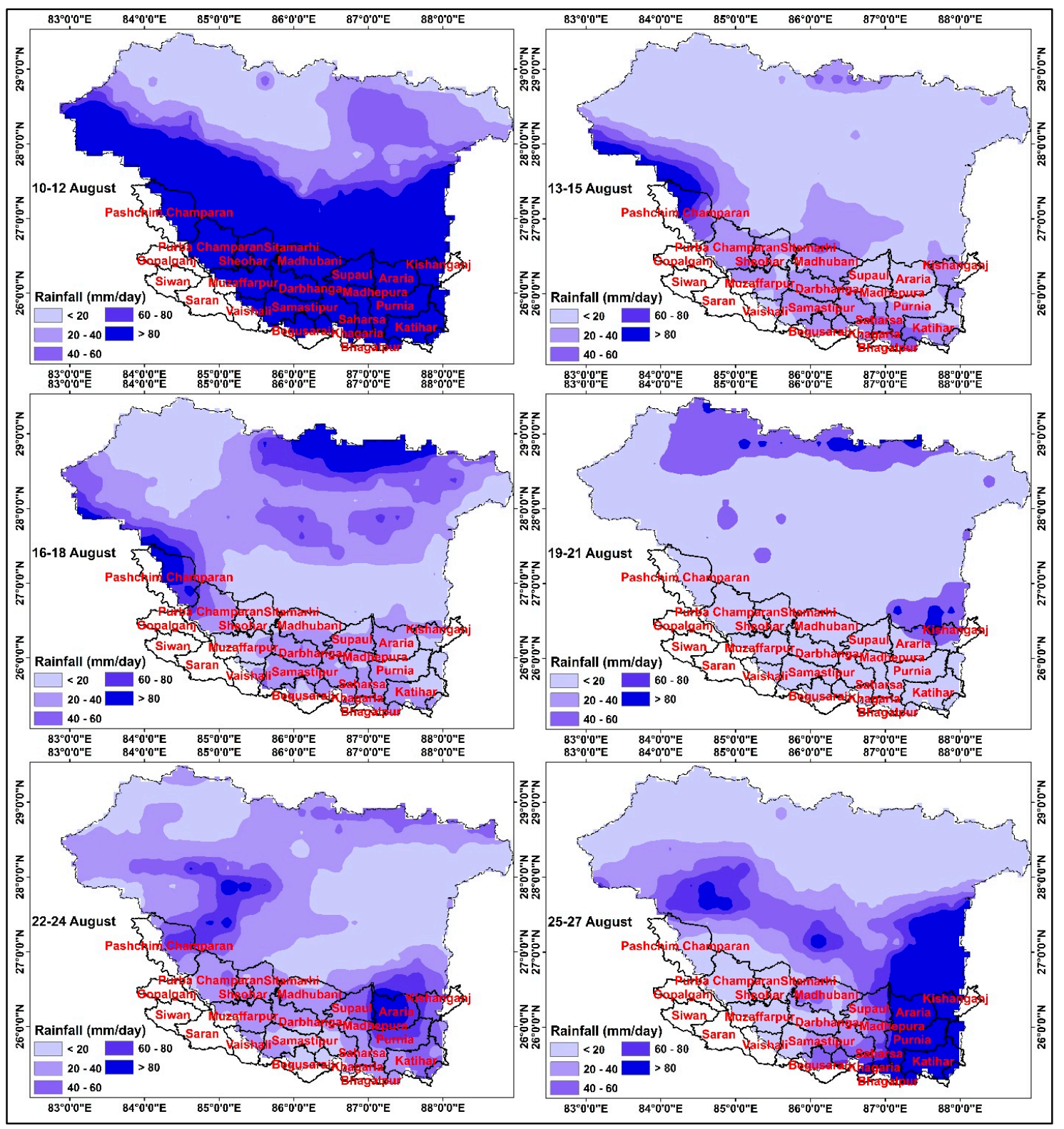

Figure 3. The accumulated spatio temporal rainfall variability $(\mathrm{mm})$ over the North Bihar during the flooding period from 10 to 27th August 2017. The shape file of the North Bihar districts was overlaid to identify the districts receiving heavy rainfall.

Concisely, it can be summarized that the higher rainfall events were observed during 10-12th, 22-24th, and 25-27th August, 2017. Those districts adversely affected by flood due to intense rainfall were Paschim and Purbi Champaran, Madhubani, Darbhanga, Supaul, Araria, Saharsa and Katihar. Apart from these, some of the districts, such as, Madhepura, Samastipur, Muzzafarpur, Purnea, Sitamarhi, Sheohar, Begusarai, Bhagalpur, Kishanganj, and Vaishali also witnessed high intensity rainfall being adversely affected.

The receding pattern of monsoonal rainfall towards the end of August 1-2nd September is also shown in Figure A1 (Appendix A). Furthermore, the daily rainfall variability is shown in Figure A2, wherein we observed that there were two peak phases of intense rainfall, such as, 10-16th August and 26th August-1st September.

The comparisons of rainfall estimates from TMPA and IMD over the Kosi and Gandak catchment area of August 2017 are given in Table 2. For most of the stations, IMD rainfall showed higher in comparison to TMPA rainfall by a factor of 1.25 during 10-16th August. By contrast, only two districts, 
namely, Bhagalpur and Madhepura showed overestimation of rainfall by TMPA than the IMD. So, it can be inferred that TMPA underestimates the rainfall to some extent against the in situ data of IMD. Despite these caveats, the satellite-based TMPA products have been widely used for flood mapping as well as allied applications because of their larger geographical coverage and continuous data at short (hourly) to long-time scales [28,30,41,52]. Bookhagen and Burbank [53] analyzed nearly 1741 gauge stations from the Himalayan-Tibetan areas and suggested that the TMPA products correlated well with the rain-gauge across an elevation of 500 to $5000 \mathrm{~m}$. Nevertheless, some studies have also suggested underestimation of TMPA-based precipitation over different basins in India [54,55].

Table 2. Rain gauge station wise accumulated rainfall (mm) over the period of 10 to 16th August, 2017 as derived from TMPA and observed from IMD.

\begin{tabular}{ccc}
\hline Stations & IMD Rainfall (mm) & TMPA Rainfall (mm) \\
\hline Sitamarhi & 283 & 220 \\
Muzzafarpur & 135 & 130 \\
Darbhanga & 322 & 256 \\
Supaul & 401 & 223 \\
Bhagalpur & 118 & 223 \\
Madhepura & 155 & 185 \\
Purnea & 333 & 178 \\
Samastipur & 244 & 164 \\
\hline
\end{tabular}

\subsection{Composite Flood Maps of MODIS-NRT during August, 2017}

The regressive and progressive flood extent based on MODIS-NRT Flood data during flood event in August 2017 is shown in Figure 4 (also in Figure A3). The inundation maps showed that during 13-14th August, the flood-induced inundated areas were 949 sq.km across North Bihar. As a consequence, it submerged the eastern part of the North Bihar districts, such as, Katihar, Purnea, Bhagalpur, and Khagaria. During 15-16th August, flood-induced inundated areas were reduced to only a 353 sq.km area. The reduced inundated areas could be explained by reduced amount of the rainfall in the upper catchment areas and that can be referred to in Figure A2. During 17-18th August, the flood-induced inundated extent further decreased to 153 sq.km. However, during 19-20th August, the inundation extent rapidly increased to $1742 \mathrm{sq} . \mathrm{km}$ as the catchment received intense rainfall. The inundation extent subsequently decreased during 21-22nd August and the inundated area was estimated as $194 \mathrm{sq.km}$ because of less rainfall occurring over the catchment during the previous four days (17-20th August) with average rainfall of $34 \mathrm{~mm}$ (Figure A2). It was evident that flood extent was categorized under high areal inundation during 23-24th, 25-26th and 29-30th August. The area was estimated as 2962, 2969, and 2545 sq.km, respectively. There were 14 out of 19 districts which were adversely affected due to floods and these districts were Katihar, Khagaria, Darbhanga, Araria, Purnea, Madhubani, Madhepura, Saharsa, Samastipur, Sheohar, Sitamarhi, Vaishali, Supaul, Paschim and Purbi Champaran. Results showed maximum flood inundation occurred during 25-26th August which submerged a 2969 sq.km area of North Bihar. The Sheohar district was the least affected district with only 8.69 sq.km of inundation. The Kishanganj and Paschim-Champaran districts were also among the least affected district with 52 and 69 sq.km of inundation, respectively. 


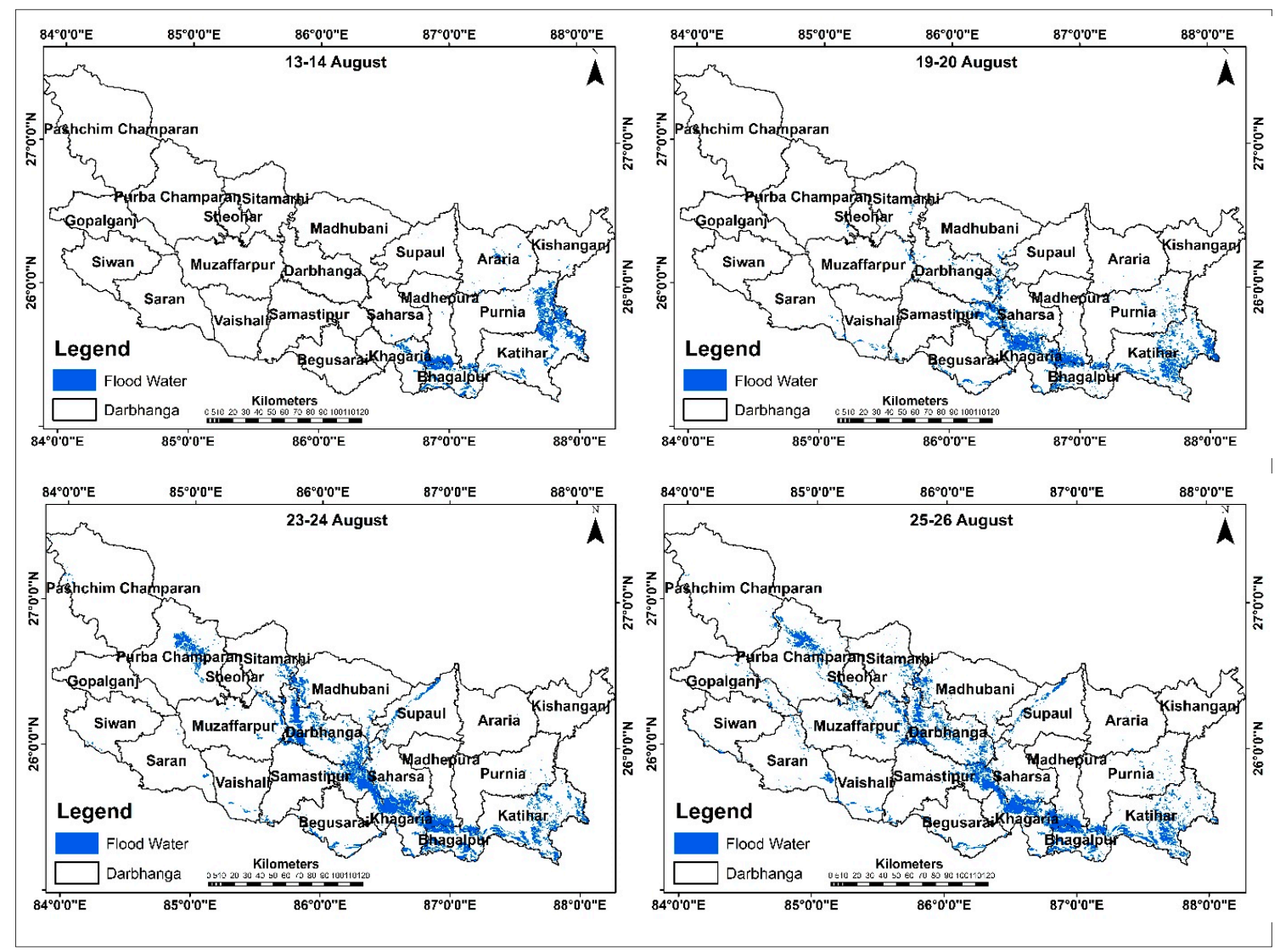

Figure 4. Flood water extent over the North Bihar districts inside Gandak and Kosi river's catchment. Only selected major flooding dates are shown.

The detailed areal flood inundation statistics and their area percentage with respect to the total North Bihar's geographical area at every 2 day intervals are provided in Table 3. These results exhibited temporal flood inundation during August and September, 2017. During 13-14th August, the flood-induced inundated area was only $2 \%$ over the North Bihar, while it diminished over the next four days owing to reduced rainfall (Figure A2). However, the flood-induced inundated area increased to $3.8 \%$ during 19-20th August. The peak inundated areas were observed during 23-24th, 25-26th, and 29-30th August and they caused inundation up to $6.45 \%, 6.47 \%$, and $5.54 \%$, respectively. After $30-31$ st August, the flood extent started receding. Over the North Bihar, the average inundation extent was estimated as 1177 sq.km. (or $2.59 \%$ ).

The four-day composite flood inundation extent is shown in Figure A4, which was computed as cumulative progression or regression of the inundation pattern. For instance, for 13-16th August, it showed composite extent of 13-14th and 15-16th August, 2017 and so on. Based on this calculation, the major progressive inundation extent was computed as 5930 sq.km. during 23-26th August (Figure A4), while, it receded after 30-31st August. We also observed that the flood inundated extent was mostly determined by the rainfall over the upstream areas and can be referred to in Figure A2.

Flood induced inundated areas (sq.km) at district level are shown in Table 4. These results exhibited that flood-induced inundated areas were persistent during August, 2017 over 19 districts of North Bihar state. However, the adversely affected districts can be listed as Darbhanga, Katihar, Khagaria, and Samastipur. The average inundated area during August, 2017 was persistently higher than 200 sq.km. Katihar was one of the most affected districts as a 324 sq.km area was inundated throughout the flooding period. Darbhanga district was inundated with an average of 269 sq.km., and it was also one of the adversely affected districts. It can be linked to the water levels at a particular gauge station (Table 5). For instance, at the Ekmighat gauge station (Darbhanga district), we observed 
that the water level crossed danger level (DL) and the water flew with an average of $48 \mathrm{~m}$. The water levels recorded at Ekmighat station also indicated the consequences of intense rainfall were started from the 10th August onwards in the upper catchment areas (Figure A2). The maximum inundated area was observed as 496 sq.km. during 23-26th August over Darbhanga district.

Table 3. MODIS-derived inundated areas (\%) with respect to total geographical area of North Bihar $(45,903$ sq.km). The bold indicates major inundations.

\begin{tabular}{ccc}
\hline Flooding Period & Inundated Area (Sq. Km.) & $\begin{array}{c}\text { Inundated area with respect } \\
\text { to North Bihar (\%) }\end{array}$ \\
\hline 13-14th August & 949.03 & 2.07 \\
15-16th August & 352.81 & 0.77 \\
17-18th August & 153.08 & 0.33 \\
19-20th August & $\mathbf{1 7 3 7 . 6 9}$ & $\mathbf{3 . 7 9}$ \\
21-22nd August & 194.31 & 0.42 \\
23-24th August & $\mathbf{2 9 6 1 . 6 4}$ & $\mathbf{6 . 4 5}$ \\
25-26th August & $\mathbf{2 9 6 8 . 8}$ & $\mathbf{6 . 4 7}$ \\
27-28th August & 768.4 & 1.67 \\
29-30th August & $\mathbf{2 5 4 4 . 8 5}$ & $\mathbf{5 . 5 4}$ \\
30-31st August & $\mathbf{1 3 1 7 . 0 6}$ & $\mathbf{2 . 8 7}$ \\
1-2nd September & 107.67 & 0.23 \\
2-3rd September & 229.57 & 0.50 \\
\hline Mean Value & 1177.37 & 2.59 \\
\hline
\end{tabular}

Table 4. District wise inundation extent (sq.km.) for the period of 13-30th August 2017. The bold indicates major inundations.

\begin{tabular}{ccccccccc}
\hline $\begin{array}{c}\text { Duration } \rightarrow \\
\text { Districts } \downarrow\end{array}$ & $\begin{array}{c}\mathbf{1 3 - 1 4} \\
\text { August }\end{array}$ & $\begin{array}{c}\mathbf{1 4 - 1 5} \\
\text { August }\end{array}$ & $\begin{array}{c}\mathbf{1 9 - 2 0} \\
\text { August }\end{array}$ & $\begin{array}{c}\mathbf{2 3 - 2 4} \\
\text { August }\end{array}$ & $\begin{array}{c}\mathbf{2 5 - 2 6} \\
\text { August }\end{array}$ & $\begin{array}{c}\mathbf{2 8 - 2 9} \\
\text { August }\end{array}$ & $\begin{array}{c}\mathbf{2 9 - 3 0} \\
\text { August }\end{array}$ & $\begin{array}{c}\text { Mean } \\
\text { Area }\end{array}$ \\
\hline Kishanganj & 10.48 & 40.11 & 0.16 & 0 & 0.27 & 0.85 & 0 & 7.41 \\
Araria & 45.44 & 178.88 & 3.72 & 0 & 5.33 & 6.17 & 3.42 & 34.71 \\
Supaul & 1.67 & 218.53 & 10.31 & 85.41 & 77.6 & 59.15 & 50.23 & 71.84 \\
Purnia & 260.63 & 286.49 & 109.92 & 48.91 & 67.65 & 18.43 & 43.16 & 119.31 \\
Katihar & $\mathbf{2 4 4 . 7 8}$ & $\mathbf{2 6 3 . 5 9}$ & $\mathbf{3 8 7}$ & $\mathbf{3 5 7 . 0 8}$ & $\mathbf{3 8 8 . 2 7}$ & $\mathbf{2 6 6 . 0 5}$ & $\mathbf{3 6 0 . 9 4}$ & $\mathbf{3 2 3 . 9 6}$ \\
Saharsa & 6.3 & 15.88 & 239.34 & 235.06 & 160.12 & 141.44 & 123.21 & 131.62 \\
Bhagalpur & 185.97 & 196.37 & 109.11 & 284.4 & 251.44 & 90.58 & 183.05 & 185.85 \\
Madhepura & 104.89 & 110.7 & 135.09 & 135.96 & 148.82 & 113.12 & 131 & 125.65 \\
Darbhanga & $\mathbf{0}$ & $\mathbf{1 . 1 8}$ & $\mathbf{1 0 4 . 0 6}$ & $\mathbf{4 9 6 . 2 3}$ & $\mathbf{4 5 2 . 1 6}$ & $\mathbf{3 9 6 . 0 9}$ & $\mathbf{4 3 3 . 6}$ & $\mathbf{2 6 9 . 0 5}$ \\
Begusarai & 0 & 20.4 & 51.82 & 64.85 & 62.37 & 24.68 & 76.2 & 42.9 \\
Khagaria & $\mathbf{8 8 . 8 7}$ & $\mathbf{1 1 7 . 8 2}$ & $\mathbf{3 0 4 . 4 1}$ & $\mathbf{3 8 9 . 6 9}$ & $\mathbf{3 5 1 . 0 8}$ & $\mathbf{2 9 3 . 9 5}$ & $\mathbf{2 7 4 . 8 7}$ & $\mathbf{2 6 0 . 1}$ \\
Samastipur & $\mathbf{0}$ & $\mathbf{1 9 . 1 6}$ & $\mathbf{1 9 3 . 2 2}$ & $\mathbf{2 9 9 . 6 6}$ & $\mathbf{2 8 4 . 8 7}$ & $\mathbf{2 8 9 . 5 3}$ & $\mathbf{3 1 8 . 5 2}$ & $\mathbf{2 0 0 . 7 1}$ \\
Vaishali & 0 & 0 & 23.74 & 15.16 & 31.8 & 22.07 & 35.02 & 18.26 \\
Madhubani & 0 & 80.15 & 29.87 & 126.14 & 107 & 105.05 & 80.45 & 75.52 \\
Sitamarhi & 0 & 3.3 & 9.48 & 76.3 & 91.17 & 88.89 & 68.36 & 48.21 \\
Sheohar & 0 & 0 & 0.06 & 0 & 2.87 & 2.7 & 3.06 & 1.24 \\
Mujjafarpur & 0 & 0.54 & 20.33 & 82.78 & 187.95 & 205.03 & 221.63 & 102.61 \\
Purba Champaran & 0 & 0 & 6.05 & 249.13 & 276.65 & 158.62 & 119.39 & 115.69 \\
Paschim Champaran & 0 & 0 & 0 & 14.32 & 21.38 & 14.9 & 18.74 & 9.91 \\
\hline Total Area & 949.03 & 1553.1 & 1737.69 & 2961.08 & 2968.8 & 2297.3 & 2544.85 & 2144.55 \\
\hline
\end{tabular}


Table 5. Central Water Commission (CWC) station-wise water levels (m) during 16-20th and 26-30th August, 2017 for LGBO-1 (Lower Ganga basin organizations). The water levels were compared with Danger Level (DL) and Highest Flood Level (HFL). The bold indicates water level above DL and HFL (Data source: CWC).

\begin{tabular}{|c|c|c|c|c|c|c|c|c|c|c|c|c|}
\hline $\begin{array}{c}\text { Duration } \rightarrow \\
\text { Stations } \downarrow\end{array}$ & HFL & DL & $\begin{array}{c}16 \\
\text { August }\end{array}$ & $\begin{array}{c}17 \\
\text { August }\end{array}$ & $\begin{array}{c}18 \\
\text { August }\end{array}$ & $\begin{array}{c}19 \\
\text { August }\end{array}$ & $\begin{array}{c}20 \\
\text { August }\end{array}$ & $\begin{array}{c}26 \\
\text { August }\end{array}$ & $\begin{array}{c}27 \\
\text { August }\end{array}$ & $\begin{array}{c}28 \\
\text { August }\end{array}$ & $\begin{array}{c}29 \\
\text { August }\end{array}$ & $\begin{array}{c}30 \\
\text { August }\end{array}$ \\
\hline Ahirwalia & 61.2 & 59.6 & 57.5 & 58.3 & 59.2 & 59.8 & 60. & 59.4 & 59.3 & 59 & 58.3 & 58 \\
\hline Baltara & 36.4 & 33.85 & 36 & 36.1 & 35.85 & 35.8 & 35.8 & 5 & 35.4 & 35.4 & 35.3 & 35.2 \\
\hline Dumariaghat & 63.6 & 62.22 & 63.9 & 64 & 63.9 & 63.4 & 63 & 62.3 & 62.2 & 62.18 & 62 & 62 \\
\hline Dhengraghat & 38 & 35.6 & 36.8 & 36.4 & 36.3 & 36 & 36 & 34.6 & 35.2 & 35.7 & 35.6 & 35.4 \\
\hline Ekmighat & 49.5 & 46.9 & 47.2 & 47.7 & 48.3 & 48.4 & 48.5 & 48.2 & 48.1 & 48 & 47.9 & 47.5 \\
\hline Khagaria & 39.3 & 36.6 & 36.1 & 36.3 & 36.4 & 36.5 & 36.6 & 37 & 37 & 37 & 37 & 37 \\
\hline Muzzafarpur & 49.2 & 47.8 & 51.4 & 51.9 & 52.4 & 52.9 & 53.3 & 53.5 & 53.4 & 48.1 & 53.2 & 53.1 \\
\hline Rosera & 46.4 & 42.6 & 41.3 & 41.7 & 42.4 & 42.7 & 43.1 & 45.5 & 45.6 & 45.6 & 45.5 & 43.4 \\
\hline Samastipur & 49.4 & 46 & 44.3 & 44.6 & 45.1 & 45.6 & 46 & 48 & 48.1 & 48.1 & 48 & 47.9 \\
\hline
\end{tabular}

Furthermore, other flood affected districts were identified as Khagaria and Samastipur, wherein the flood-induced areas were estimated as above $200 \mathrm{sq} . \mathrm{km}$. Baltara and Khagaria gauge stations of Khagaria district showed that the water level crossed DL (33.85 and $36.6 \mathrm{~m}$ ) during 16-30th August, but remained within the HFL limit as 36.4 and $39.3 \mathrm{~m}$, respectively (Table 5). The flood inundated area was estimated as 260 sq.km. (average) for Khagaria district. Samastipur district was also one of the adversely affected districts. It was observed that at Rosera gauge station (Samastipur district), the water level crossed the DL after the 19th August onwards due to excess rainfall. The Samastipur station also exhibited that the water level crossed DL after the 26th August and consequently, inundated agriculture fields and other LU/LC of the Samastipur district. The average inundation area was estimated as 201 sq.km (Figure A2). It can be also noted that the water levels, such as, DL, HFL, and warning levels at the various gauge stations were typically measured continuously by CWC in order to take control measures for future flood events.

It was evident that among all the affected districts, Katihar was the most affected one followed by Darbhanga, Khagaria and Samastipur (Table 4). In particular, we observed that $\sim 324$ sq.km area of the Katihar district was flood affected and the temporal variability of flood progression and regression can be viewed in Figure 5. Flood induced inundated areal percentage was highest at $17 \%$ (388 sq.km) during 25-26th August, 2017 due to excess rainfall over the catchment. It can be also stated that the Katihar district is geographically situated along the bank of the Kosi Ganga river Sangam and thereby, it could be the most prominent cause of being most inundated apart from the excess rainfall along with the seasonal channels (called as "dhars"). There was also no bund (barrier) along the Kosi to restrict flood water from inundating Katihar district. It was reported that Katihar district was categorized under very high waterlogging hazard, wherein $40-60 \%$ of areas were affected by waterlogging [19]. It was noticed that flood inundated areas in Katihar district mostly affected agricultural and urban patches. So, every time when flooding occurs, it affects standing crops, such as rice, maize, sugarcane, banana, barley, vegetables, fruits (banana, litchi, watermelon, coriander) etc.

The ASTER-based global DEM (version 2) was used to derive drainage patterns and flow directions over the catchment area (Figure 6). The drainage map displayed major and minor water channels, which drain to the main river inside the catchment. The flow direction map further assisted the location of the flow route inside the basin boundary through which flood water inundates the lower catchment areas. By overlaying the drainages and flow direction over MODIS flood NRT data, it was revealed that the areas with higher drainage density showed higher inundation extent. Subsequently, the flow direction appeared towards the inundated areas. These results indicated the applicability of DEM maps to delineate the risk zones. 


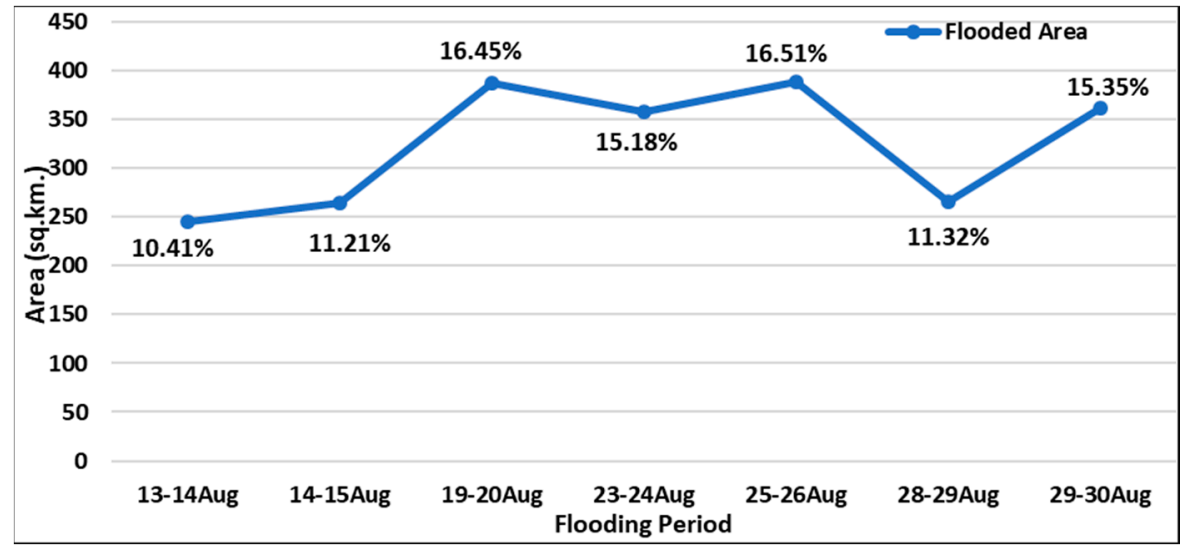

Figure 5. Flood inundation area (sq.km) over Katihar district during 13-30th August 2017. The total geographical area of the district is 2351 sq.km.
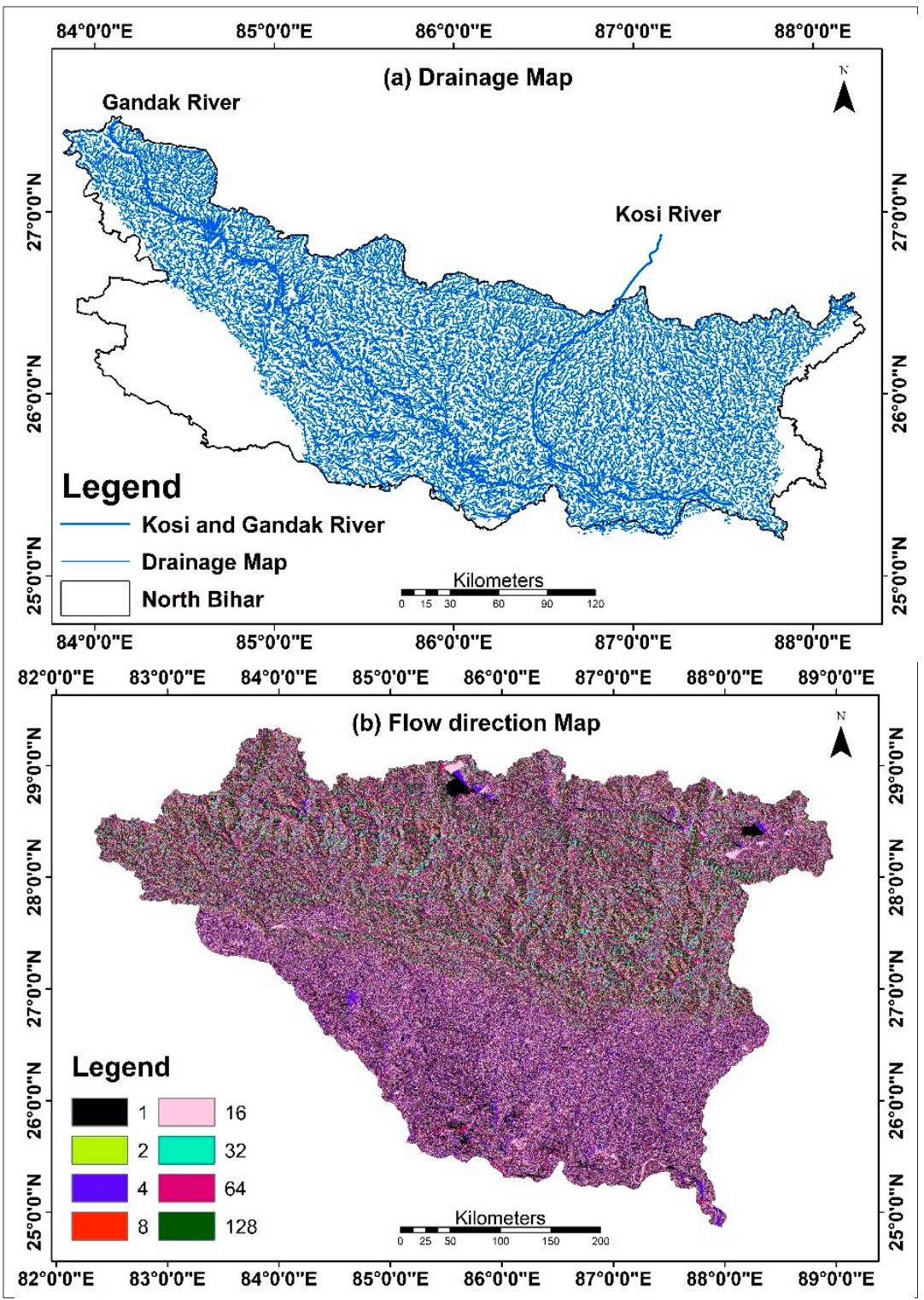

Figure 6. Drainage network (a) and flow direction (b) map derived from ASTER GDEMV2.0 dataset for the Kosi and Gandak river's catchment. The shape files of the Kosi and Gandak rivers are also overlaid on the map. 


\subsection{Comparison of Flood Extent of MODIS NRT Flood Data with Sentinel-1 SAR and Landsat-8 OLI Data}

Flood inundation extent as obtained from MODIS NRT Flood data was compared and validated against the Sentinel-1 SAR data and Landsat- 8 data over the Darbhanga district. The Darbhanga district was one of the most affected districts, and thus considered for validation. The spatial distribution of flood extent was comparable to each other (Figure 7), while optical False Color Composite (FCC) image showed cloud contamination (Figure 7a). The flood extent area was $456 \mathrm{sq} . \mathrm{km}$ in MODIS NRT flood data during 22-23rd August (i.e., mean of 2 days composite), while 286 sq.km in SAR data on 23rd August. The flood extent was overestimated in MODIS NRT and mostly attributed to sensor's resolution $(250 \mathrm{~m})$ capability (coarser) than the SAR $(10 \mathrm{~m})$ data. There will be less possibility of error in Sentinel-1 data in comparison to MODIS NRT Flood product. Thereby, flood inundation extent provided by MODIS NRT data may have overestimated area under flood in other districts as well.

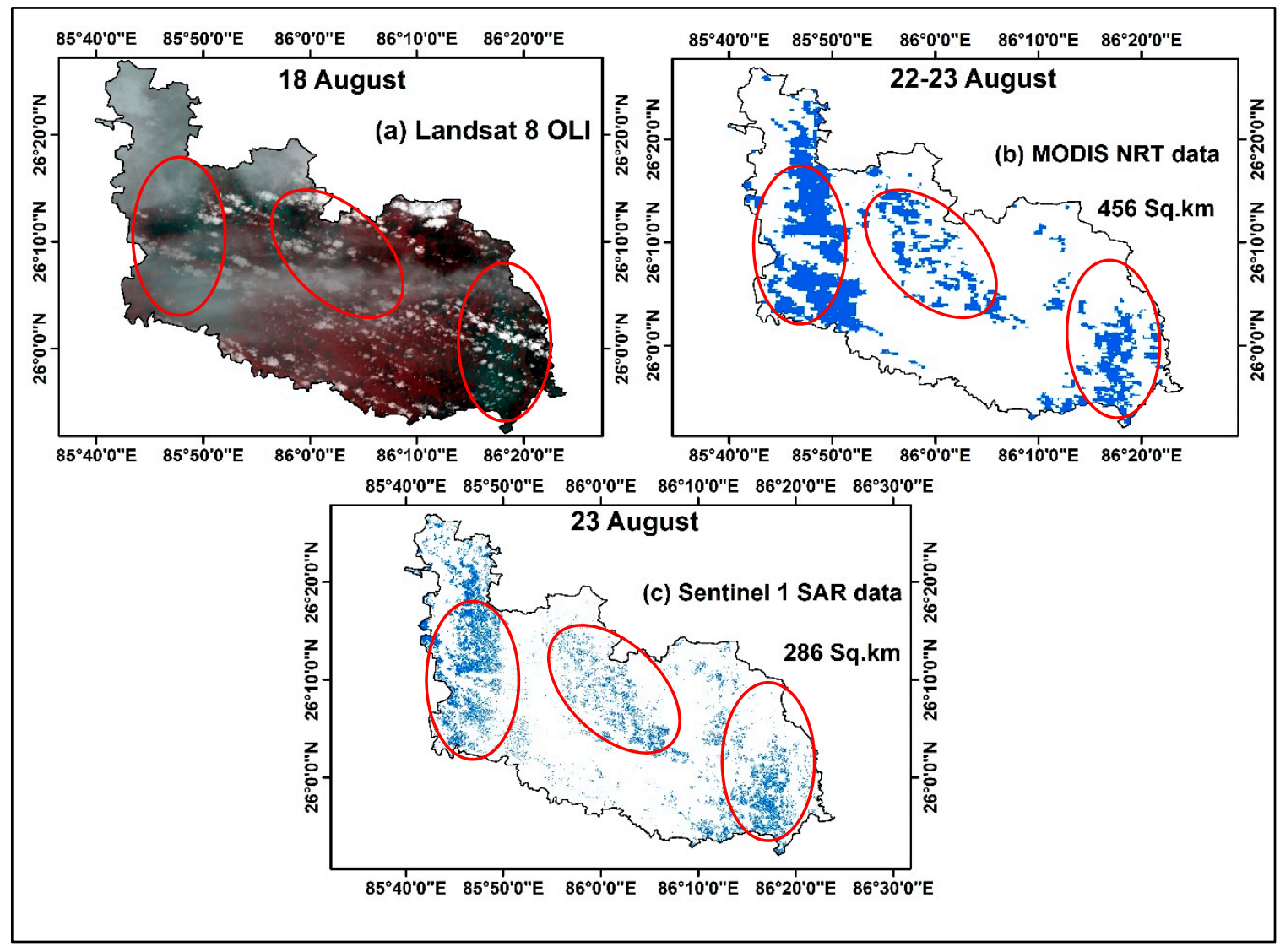

Figure 7. Flood extent map of MODIS NRT (b) and Sentinel-1A SAR (c) data over the Darbhanga district was shown during 22-23th August and 23rd August, respectively. The Landsat-8 (OLI) FCC image (a) of 18th August, 2017 was also used to verify flooding extent. The red circle indicates some of the continuous patch of flood.

\section{Discussion}

There were no such comprehensive studies available over North Bihar that discussed flood progression at shorter time-scales with two day intervals using space-based satellite technologies. Hence, we aimed to analyze the flood event of 2017 as a case study over North Bihar, which occurred during August and September months. The methodology adopted was very simple and intended to provide a framework for a non-expert community to produce NRT flood maps over larger geographical areas and further, this information could assist in flood risk management. Indeed, these flood maps are very useful to the community or nations where hydrometeorological data are sparse or real time data are not available. The adopted framework can be also operated where hydrological models 
cannot be used owing to limitation in input parameters. It has been identified that in developing countries in Asia including India, Nepal and Bangladesh, that an effective flood monitoring and forecasting system has been lacking mainly due to inadequate resources as well as the fragile coping capacity of society/institutions [2]. In this respect, a semi-automatic method consisting of multi-sensor (MODIS, Proba-V, Sentinel-3) data and low-cost approach has been suggested for flood inundation mapping [56]. Very often, the required high-resolution data during flood events are not free and thus, the methodology adopted in this study ascertains to be a good trade-off between emergency real-time automatic flood mapping and the latest flood mapping performed with hydrological models. Albeit, the real-time automatic flood mapping using satellite data are fast, they may not be very accurate [56]. Despite the spatial resolution of the MODIS-based NRT product being comparatively coarse $(\sim 250 \mathrm{~m})$, it is still one of the most significant sources to assist flood assessment all over the world. Prior studies also applied the NRT product in flood mapping and discussed its application and underlying uncertainties $[26,57,58]$.

Here, we presented the 2017 flood event as a case study in the Kosi and Gandak river catchment, wherein both rainfall variability and rainfall-induced flood progression and regression were analyzed. The rainfall-induced flood inundation extent was discussed at 2-4 days composite using the multitemporal MODIS-based NRT flood product. Further, the rainfall variability was discussed at 2 day intervals based on the rainfall data from TMPA as well as IMD. The station-wise water levels data of CWC were used to monitor and validate the flooding in 2017. Our key findings based on the MODIS NRT flood product revealed that the maximum flood inundation extent (or flood progression) was observed on 25-26th August with an inundated area of $\sim 2969$ sq.km, while, the flood regression was observed in multi-dates, namely, 17-18th August, 21-22nd August, wherein the flood-induced inundation extent was 153 and 194 sq.km, respectively, and finally retreated from 1-2nd September, and thereafter.

We have also validated flooding extent of MODIS NRT flood data against the Sentinel-1 (SAR) and Landsat-8 OLI data (Figure 7). The inundation extent over the Darbhanga district on 18th August (Landsat-8 OLI) and 23rd August (Sentinel-1) was taken into account to validate with the MODIS NRT flood data of 22-23rd August. The spatial inundation extent over the Darbhanga district was clearly shown inside red circles in the satellite images (Figure 7). The areal extent during the flooding period was showed the spatial pattern of inundated are very similar in nature. Because of higher spatial resolution of Sentinel-1 (SAR) data, they offered more precise inundation extent Figure 7c than the other dataset $[14,15]$.

From the flood progression and regression analysis, it can be inferred that rainfall is a driving factor of floods over the Kosi and Gandak catchment in North Bihar. It was observed that continuous and intense rainfall increased water levels at various gauge stations, and further caused inundation in low land areas of North Bihar. The flood event of August 2017 was primarily initiated by extreme rainfall events. Subsequently, it generated high surface runoff and caused flooding over North Bihar. Further, the seasonal water channels called "dhars" may have poured a heavy amount of water into the main stream that could have increased the risk of flood in North Bihar. Some of these dhars may take the shape of a small river. In line of the above findings, Sinha et al. [21] and Pandey et al. [59] suggested that rivers typically carried high flows of water from the upper catchment (Nepal regions) towards low lying areas of the North Bihar plain owing to heavy rainfall. In some cases, high river flows could lead to the breaking of embankments [35,36] and changes in the river course causing flooding is areas of the Kosi and Gandak catchment in North Bihar [60]. For instance, the flood of 2008 in Kosi River was mostly attributed to a collapse of the embankment near the Kushaha village of Sunsari district at the Indo-Nepal border and as a result, it caused flooding in Purnia, Madhepura, Saharsa, Supaul, Kahagaria, Katihar and Araria districts [61,62]. In the 2010 flood event, it was reported that Khagaria, Supaul, Araria, Katihar, and Madhepura districts were most adversely affected and the detailed flood maps based on ALOS and RADASAT satellite can be found in Amarnath et al. [63] and FMISC Flood Report [34].

Satellite and in situ based rainfall dataset clearly displayed that the excessive rainfall was the main cause of floods over the North Bihar region, which probably induced conditions for breaching of 
the embankment at several places. In this regard, studies have suggested that nowadays embankments have played a very major role in increasing the intensity of flooding in Bihar $[35,36]$. The embankments often breached and caused severe damages to live and livestock. As per the CWC report, it suggested that the embankments were breached more than 371 times in the last 24 years [64].

The key quantitative estimates revealed that $\sim 6.5 \%$ of the North Bihar region was affected by the August, 2017 flood event. The adversely affected districts were Katihar (324 sq.km), Darbhanga (269 sq.km), Khagaria (260 sq.km), and Samastipur (201 sq.km). It can be stated that the maximum inundation extent was $\sim 17 \%$ and $\sim 12 \%$ of the geographical area of Katihar and Darbhanga districts, respectively. It was reported that these districts were categorized under very high waterlogging hazard, wherein $40-60 \%$ of areas were affected by waterlogging [19]. These districts were also known for high flood waterlogging risk zones [19]. Due to the August, 2017 flood event, it was noticed that the standing agricultural crops were adversely affected and caused a reduction in crop yields. Besides agriculture, flood event even affected the urban areas of affected districts. In line with our findings, Pandey et al. reported that during floods at the Kosi and Gandak river catchment, agriculture and urban patches were most commonly affected LU/LC [18].

The flood progression and regression analysis were also supported by the gauge-based water levels. Our key findings suggested that the flood progression and regression pattern were well supported by the runoff data at various gauge stations of CWC (Table 5). Thereby, the water level data of CWC has assisted in monitoring the flood prognosis in the North Bihar region. Rainfall generally triggers the runoff which is the quantity of water discharged in surface streams. It directly depends on the amount of precipitation occurring in the upper catchment. A steep slope also acts as one of the major factors for a sudden increase in the runoff volume $[65,66]$. Hydrographs have exhibited that after receiving heavy rainfall over a catchment, runoff estimates were high. Historically over the North Bihar region, flood events were observed in 1987, 1998, 2000, 2001, 2003, 2004, 2008, 2010, 2013, 2017, and 2018. The increasing frequency and intensity of flooding could be attributed to LU/LC by humans in the flood plains. Some studies have also indicated that climate change or anthropogenic activities may have caused recurring flood events in the North Bihar region $[67,68]$.

In this study, we compared satellite-derived rainfall (TMPA) against the observational point data of IMD across North Bihar. Typically, the station based IMD rainfall is more reliable and accurate. We found that the TMPA-based rainfall was underestimated against IMD by a factor of 1.25. Despite these caveats, the satellite-derived rainfalls are being used because they are the only source to fill the data gap at pixel levels. Thus, the satellite-derived rainfall has become essential to monitor such flooding events [32]. The combination of in situ and satellite-derived dataset may also provide more accurate and relevant rainfall information, which could be further, implemented for better planning, preparedness and mitigation exercises. In this regard, a number of applications have been undertaken that suggest the utility of satellite-derived rainfall during extreme rainfall events, such as, flood and drought.

As per the FMIS Flood Report, it was concluded that Katihar, Khagaria, Darbhanga, Samastipur, Saharsa, Purnea, and Mujjafarpur districts were severely affected by the 2010 flood event [34], triggered by intense rainfall in the upper catchment areas of North Bihar region. Our findings also indicated that many districts along the Kosi and Gandak river basins were adversely affected due to the flood event in August 2017. It can be highlighted that floods along the Ganga river are not destructive as compared to floods along the Kosi and Gandak river. This is mainly because of the geography of the Kosi and Gandak river, wherein the water flow is mainly from the Nepal region. Furthermore, the slope of the Kosi and Gandak river's catchment is more pronounced as compared to the Ganga river's channel that has led to submerging of areas due to floods.

\section{Conclusions}

Optical sensors data have demonstrated the capability of flood detection but they depend on percentage of cloud cover. The availability of composite data, such as the MODIS-based NRT Flood product developed by NASA/DFO has proven beneficial to monitor and assess the flood-induced 
inundation extent over a larger geographical area. It has been a known fact that the availability of a meteorological and hydrological dataset is limited over the North Bihar region, but these datasets are used in playing a crucial role in assessing pre-, during- and post- flooding conditions. From this comprehensive study, it could be concluded that the MODIS-based NRT flood data might be used effectively to assess flood progression and regression over the North Bihar region. However, it was also noticed that the flood extent derived from MODIS NRT data have overestimated area under flood but preserved the spatial pattern of flood. The spatio temporal variability of rainfall and consequent flood progression and regression were well captured by the MODIS-based NRT flood data. Although the methodology adopted was very simple, it can still help the non-expert community to produce NRT flood maps in data-sparse regions to support flood risk management. Nevertheless, the spatiotemporal mapping of flood progression and regression could be also delineated accurately using SAR data and hydrological models. Based on the NRT flood product, it can be concluded that most of the areas of the districts of the Kosi and Gandak river catchment were affected by flooding during August 2017. It was apparent that during the peak flooding 12\% to 17\% of the geographical area of the Darbhanga and Katihar districts were affected, respectively. Over the North Bihar region, it was estimated that only $\sim 6.5 \%$ of the area was affected by flooding during August 2017.

DEM data at fine resolution are also limited but very useful to compute various parameters, such as, flow accumulation, direction, drainage density. All these parameters are beneficial in order to locate possible high vulnerable risk zones for the flood water accumulation zones with the possible flooding route and to identify the evacuation route [64]. Nevertheless, all these data could be integrated to capture flood disaster footprints with reasonably higher accuracy. Further, the future scope of the study can be extended by mapping flood progression and regression using SAR data along with hydrological models.

Some of the limitations of this study are unavailability of satellite data and hydraulic parameters during the flooding period. Optical satellite data are passive sensors and during flood events, these data have limitations for mapping flooding owing to cloud cover. The SAR sensor has a limitation in their temporal resolution and at frequent intervals SAR data are not available during flood events. Thereby, hydrological models and machine learning techniques can be integrated along with the satellite data for delineating and mapping flood progression and regression [5-8,48-51]. However, hydraulic parameters, such as discharge, slope, hydraulic conductivity, surface roughness, and runoff coefficient could be used for flood inundation mapping and some of these hydraulic parameters can be set according to land use and soil type distributions.

Author Contributions: A.C.P. and B.R.P. designed the research concept. G.T. and B.R.P. performed the data analysis and prepared the manuscript. A.C.P. edited the manuscript and provided constructive comments and suggestions.

Funding: This research received no external funding.

Acknowledgments: Our sincere thanks to NASA GES/DISC and LP-DAAC for providing satellite-based rainfall products and MODIS NRT Flood product, respectively. We thank IMD and CWC for providing station-wise rainfall and hydrographs, respectively. Gaurav Tripathi received a fellowship from Central University of Jharkhand, Ranchi to pursue his doctoral studies.

Conflicts of Interest: Authors declare no conflict of interest. 


\section{Appendix A}

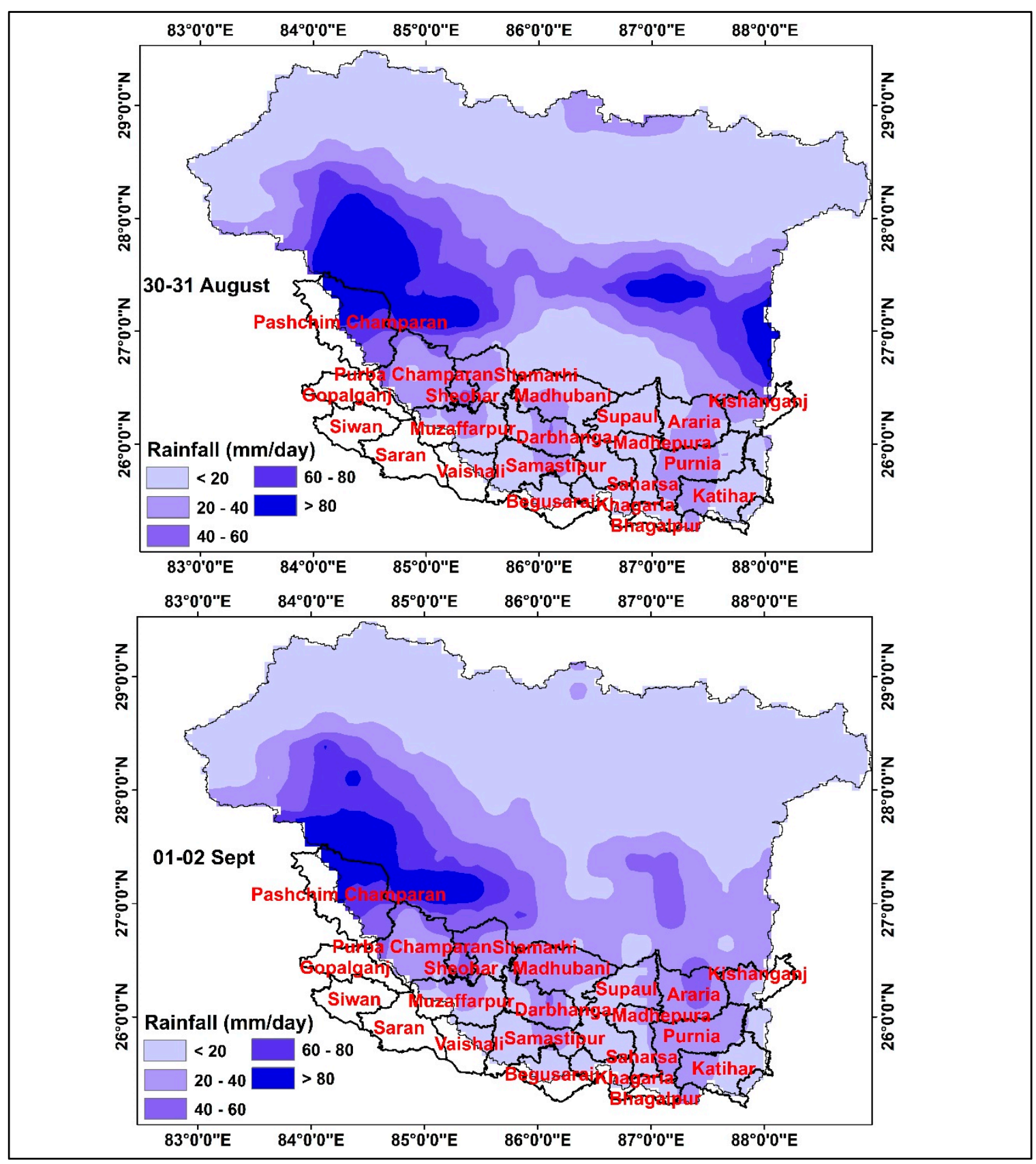

Figure A1. Rainfall variability over North Bihar during 30-31st August and 1-2nd September, 2017. 


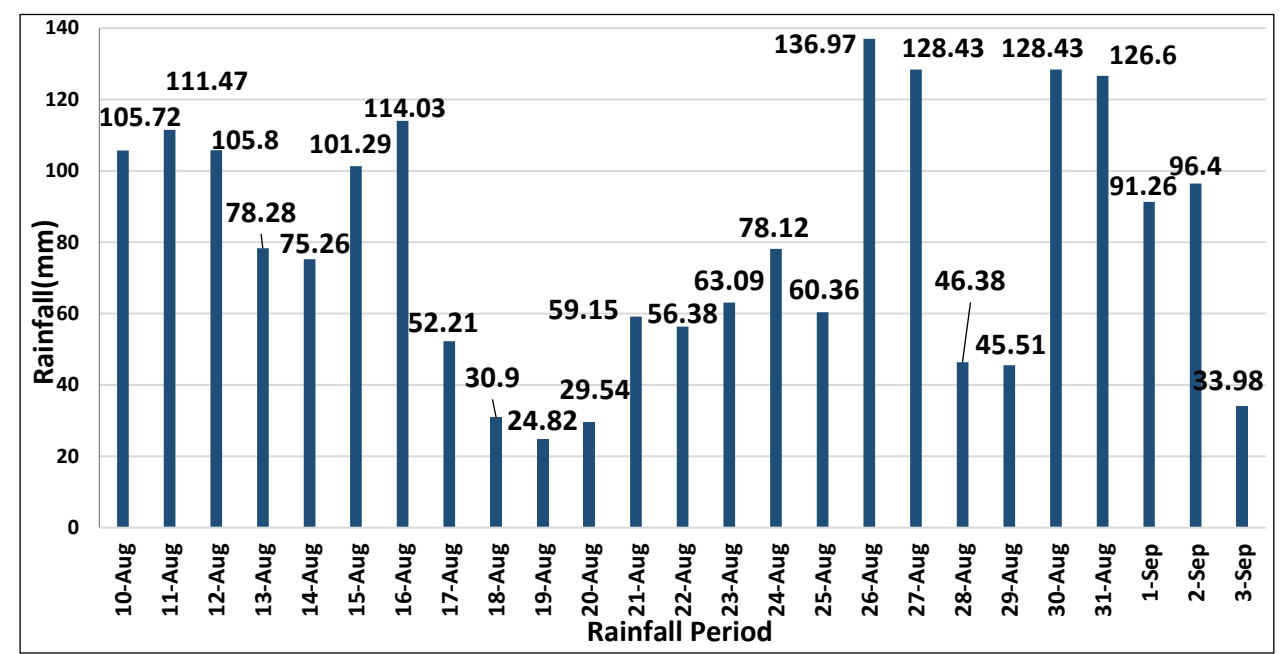

Figure A2. Daily rainfall amount over the Kosi and Gandak river catchment (mm) during flooding period from 10 August-3rd September, 2017 as derived from TRMM (3B42RT) data.

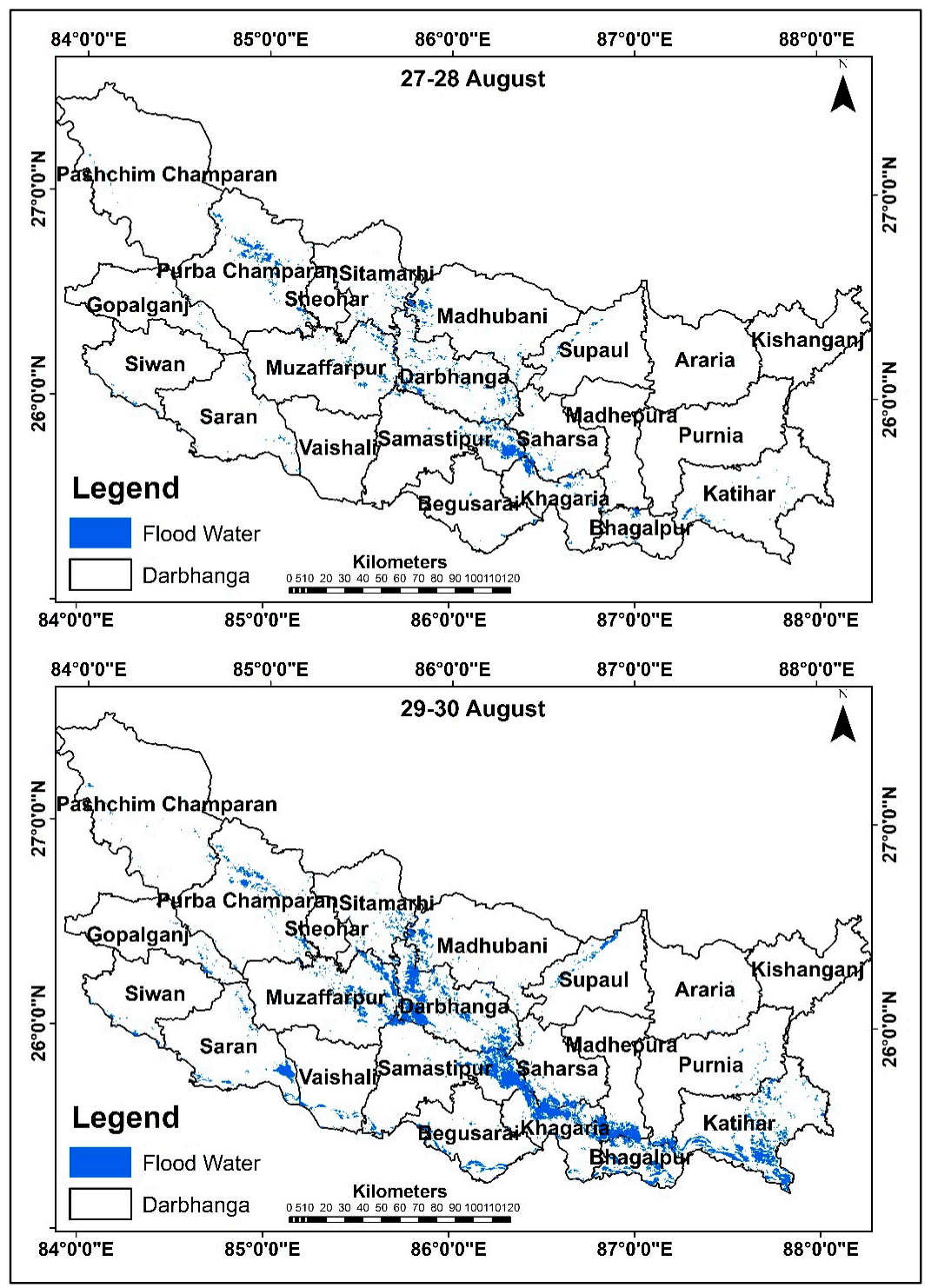

Figure A3. Flood inundation extent as derived from MODIS Flood NRT data during 27-28th \& 29-30th August, 2017. 


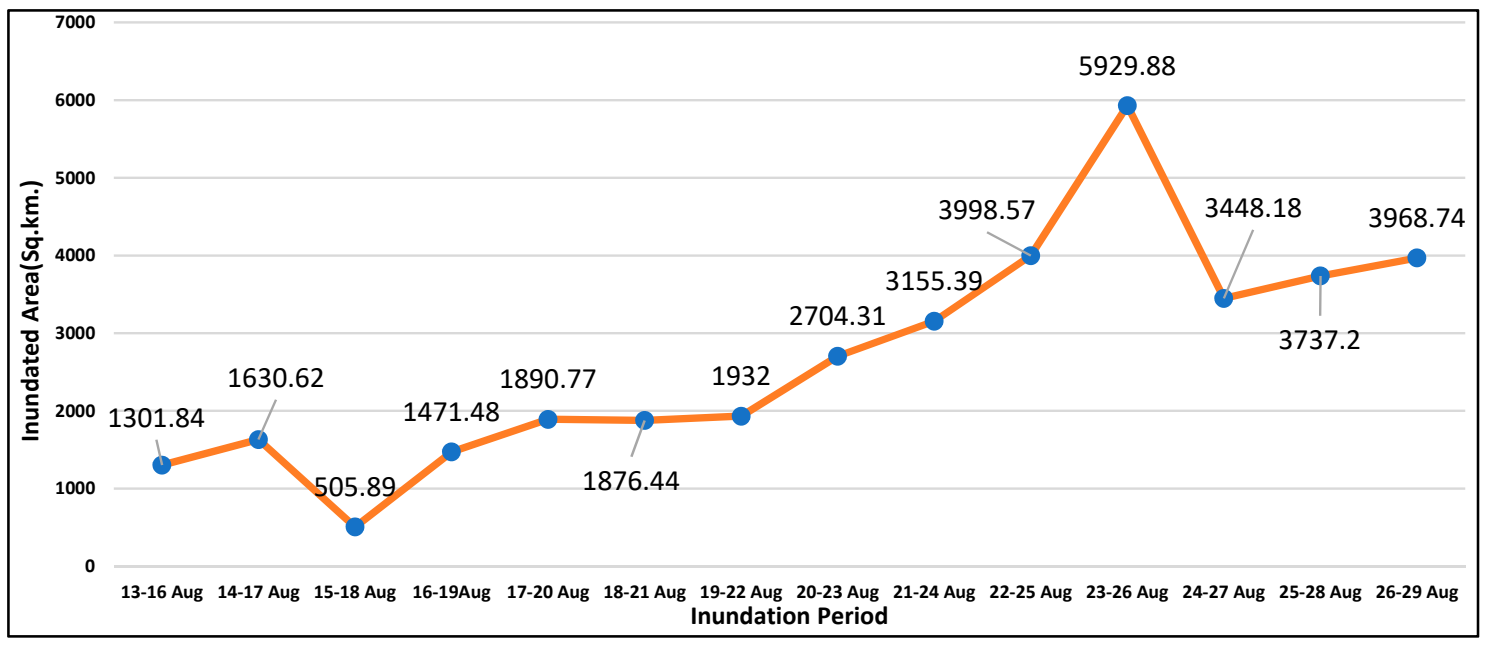

Figure A4. Four-day cumulative composite flood progressive and regressive pattern during 13-29th August, 2017.
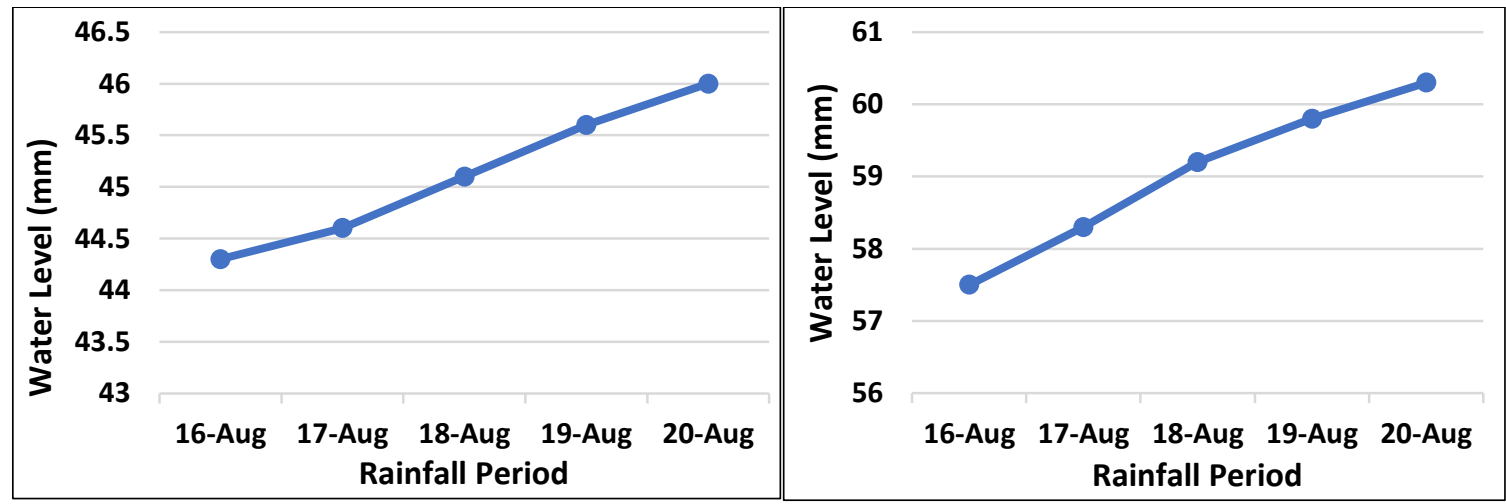

Figure A5. Water level ( $\mathrm{mm})$ recorded at Ahirwalia and Samastipur gauge stations of CWC during 16-20th August, 2017.

\section{References}

1. Freer, J.; Beven, K.J.; Neal, J.; Schumann, G.; Hall, J.; Bates, P. Flood Risk and Uncertainty. Risk and Uncertainty Assessment for Natural Hazards; Cambridge University Press: Cambridge, UK, 2011.

2. Wu, H.; Adler, R.F.; Hong, Y.; Tian, Y.; Policelli, F. Evaluation of Global Flood Detection Using Satellite-Based Rainfall and a Hydrologic Model. J. Hydrometeorol. 2012, 13, 1268-1284. [CrossRef]

3. Martinis, S.; Kersten, J.; Twele, A. A fully automated TerraSAR-X based flood service. Isprs J. Photogram Remote Sens. 2015, 104, 203-212. [CrossRef]

4. Twele, A.; Cao, W.; Plank, S.; Martinis, S. Sentinel-1-based flood mapping: A fully automated processing chain. Int. J. Remote Sens. 2016, 37, 2990-3004. [CrossRef]

5. Teng, J.; Jakeman, A.J.; Vaze, J.; Croke, B.F.W.; Dutta, D.; Kim, S. Flood inundation modelling: A review of methods, recent advances and uncertainty analysis. Environ. Model. Softw. 2017, 90, 201-216. [CrossRef]

6. Afshari, S.; Tavakoly, A.A.; Rajib, M.A.; Zheng, X.; Follum, M.L.; Omranian, E.; Fekete, B.M. Comparison of new generation low-complexity flood inundation mapping tools with a hydrodynamic model. J. Hydrol. 2018, 556, 539-556. [CrossRef]

7. Speckhann, G.A.; Borges Chaffe, P.L.; Fabris Goerl, R.; de Abreu, J.J.; Altamirano Flores, J.A. Flood hazard mapping in Southern Brazil: A combination of flow frequency analysis and the HAND model. Hydrol. Sci. J. 2018, 63, 87-100.

8. McGrath, H.; Bourgon, J.-F.; Proulx-Bourque, J.-S.; Nastev, M.; Abo El Ezz, A. A comparison of simplified conceptual models for rapid web-based flood inundation mapping. Nat. Hazards 2018, 93, 905-920. [CrossRef] 
9. Grimaldi, S.; Li, Y.; Pauwels, V.R.N.; Walker, J.P. Remote Sensing-Derived Water Extent and Level to Constrain Hydraulic Flood Forecasting Models: Opportunities and Challenges. Surv. Geophys. 2016, 37, 977-1034. [CrossRef]

10. Mure-Ravaud, M.; Binet, G.; Bracq, M.; Perarnaud, J.-J.; Fradin, A.; Litrico, X. A web based tool for operational real-time flood forecasting using data assimilation to update hydraulic states. Environ. Model. Softw. 2016, 84, 35-49.

11. Gan, T.Y.; Zunic, F.; Kuo, C.-C.; Strobl, T. Flood mapping of Danube River at Romania using single and multi-date ERS2-SAR images. Int. J. Appl. Earth Obs. Geoinf. 2012, 18, 69-81. [CrossRef]

12. Alsdorf, D.E.; Rodríguez, E.; Lettenmaier, D.P. Measuring surface water from space. Rev. Geophys. 2007. [CrossRef]

13. Schlaffer, S.; Matgen, P.; Hollaus, M.; Wagner, W. Flood detection from multi-temporal SAR data using harmonic analysis and change detection. Int. J. Appl. Earth Obs. Geoinf. 2015, 38, 15-24. [CrossRef]

14. Matgen, P.; Hostache, R.; Schumann, G.; Pfister, L.; Hoffmann, L.; Savenije, H.H.G. Towards an automated SAR-based flood monitoring system: Lessons learned from two case studies. Phys. Chem. Earth 2011, 36, 241-252. [CrossRef]

15. Mason, D.C.; Giustarini, L.; Garcia-Pintado, J.; Cloke, H.L. Detection of flooded urban areas in high resolution Synthetic Aperture Radar images using double scattering. Int. J. Appl. Earth Obs. Geoinf. 2014, 28, 150-159. [CrossRef]

16. Iervolino, P.; Guida, R.; Iodice, A.; Riccio, D. Flooding water depth estimation with high-resolution SAR. IEEE Trans. Geosci. Remote Sens. 2015, 53, 2295-2307. [CrossRef]

17. Chandran, R.V.; Ramakrishnan, D.; Chowdary, V.M.; Jeyaram, A.; Jha, A.M. Flood mapping and analysis using air-borne synthetic aperture radar: A case study of July 2004 flood in Baghmati river basin, Bihar. Curr. Sci. 2006, 90, 249-256.

18. Pandey, A.C.; Singh, S.K.; Nathawat, M.S. Waterlogging and flood hazards vulnerability and risk assessment in Indo Gangetic plain. Nat. Hazards 2010, 55, 273-289. [CrossRef]

19. Singh, S.K.; Pandey, A.C.; Nathawat, M.S. Rainfall variability and spatio temporal dynamics of flood inundation during the 2008 Kosi flood in Bihar State, India. Asian J. Earth Sci. 2011, 4, 9-19. [CrossRef]

20. Kafle, K.R.; Khanal, S.N.; Dahal, R.K. Consequences of Koshi flood 2008 in terms of sedimentation characteristics and agricultural practices. Geoenviron. Disasters 2017, 4, 4. [CrossRef]

21. Sinha, R.; Bapalu, G.V.; Singh, L.K.; Rath, B. Flood risk analysis in the Kosi river basin, north Bihar using multi-parametric approach of Analytical Hierarchy Process (AHP). J. Indian Soc. Remote Sens. 2008, 36, 335-349. [CrossRef]

22. Macchione, F.; Costabile, P.; Costanzo, C.; De Santis, R. Moving to 3-D flood hazard maps for enhancing risk communication. Environ. Model. Softw. 2019, 111, 510-522. [CrossRef]

23. Wahab, A.M.; Muhamad Ludin, A.N. Flood vulnerability assessment using artificial neural networks in Muar Region, Johor Malaysia. IOP Conf. Ser. Earth Environ. Sci. 2018, 169, 012056. [CrossRef]

24. Kussul, N.; Shelestov, A.; Skakun, S. Grid system for flood extent extraction from satellite images. Earth Sci. Inform. 2008, 1, 105-117. [CrossRef]

25. Moradkhani, H.; Sorooshian, S. General review of rainfall-runoff modeling: Model calibration, data assimilation, and uncertainty analysis. In Hydrological Modelling and the Water Cycle; Springer: Berlin, Germany, 2009.

26. Revilla-Romero, B.; Wanders, N.; Burek, P.; Salamon, P.; de Roo, A. Integrating remotely sensed surface water extent into continental scale hydrology. J. Hydrol. 2016, 543, 659-670. [CrossRef] [PubMed]

27. Huffman, G.J.; Bolvin, D.T.; Nelkin, E.J.; Wolff, D.B.; Adler, R.F.; Gu, G.; Hong, Y.; Bowman, K.P.; Stocker, E.F. The TRMM multisatellite precipitation analysis (TMPA): Quasi-global, multiyear, combined-sensor precipitation estimates at fine scales. J. Hydrometeorol. 2007, 8, 38-55. [CrossRef]

28. Su, F.; Gao, H.; Huffman, G.J.; Lettenmaier, D.P. Potential Utility of the Real-Time TMPA-RT Precipitation Estimates in Streamflow Prediction. J. Hydrometeorol. 2011, 12, 444-455. [CrossRef]

29. Wu, H.; Adler, R.F.; Tian, Y.; Huffman, G.J.; Li, H.; Wang, J. Real-time global flood estimation using satellite-based precipitation and a coupled land surface and routing model. Water Resour. Res. 2014, 50, 2693-2717. [CrossRef]

30. Parida, B.R.; Behera, S.N.; Bakimchandra, O.; Pandey, A.C.; Singh, N. Evaluation of satellite-derived rainfall estimates for an extreme rainfall event over Uttarakhand, Western Himalayas. Hydrology 2017, 4, 22. [CrossRef] 
31. Belabid, N.; Zhao, F.; Brocca, L.; Huang, Y.; Tan, Y. Near-Real-Time Flood Forecasting Based on Satellite Precipitation Products. Remote Sens. 2019, 11, 252. [CrossRef]

32. Shrestha, M.S.; Artan, G.A.; Bajracharya, S.R.; Sharma, R.R. Using satellite-based rainfall estimates for streamflow modelling: Bagmati Basin: Rainfall estimates for streamflow modelling. J. Flood Risk Manag. 2008, 1, 89-99. [CrossRef]

33. Pan, M.; Li, H.; Wood, E. Assessing the skill of satellite-based precipitation estimates in hydrologic applications: satellite precipitation skill. Water Resour. Res. 2010. [CrossRef]

34. Samaiyar, A.K. Flood Management Improvement Support Center (FMISC). Flood Report 2013. Water Resources Department. Goverment of Bihar; FMISC, Patna: Patna, India, 2013; pp. 1-65.

35. Sinha, R. The great avulsion of Kosi on 18 August 2008. Curr. Sci. 2009, 97, 429-433.

36. Reddy, D.V.; Kumar, D.; Saha, D.; Mandal, M.K. The 18 August 2008 Kosi river breach: An evaluation. Curr. Sci. 2008, 95, 1668-1669.

37. National Disaster Management Authority (NDMA), Annual Report 2016-17; Government of India: New Delhi, India, 2017.

38. Sinha, G.P. The State Disaster Management Plan, Disaster Management Department, Govt of Bihar; Disaster Management Department: Patna, India, 2013; pp. 50-89.

39. Nigro, J.; Slayback, D.; Policelli, F.; Brakenridge, G.R. NASA/DFO MODIS Near Real-Time (NRT) Global Flood Mapping Product Evaluation of Flood and Permanent Water Detection; NASA GSFC MODIS Flood Mapping Products, NASA: Washington, DC, USA, 2014.

40. Parida, B.R.; Behera, S.N.; Oinam, B.; Patel, N.R.; Sahoo, R.N. Investigating the effects of episodic Super-cyclone 1999 and Phailin 2013 on hydro-meteorological parameters and agriculture: An application of remote sensing. Remote Sens. Appl. Soc. Environ. 2018, 10, 128-137. [CrossRef]

41. Li, Z.; Yang, D.; Gao, B.; Jiao, Y.; Hong, Y.; Xu, T. Multiscale Hydrologic Applications of the Latest Satellite Precipitation Products in the Yangtze River Basin using a Distributed Hydrologic Model. J. Hydrometeorol. 2015, 16, 407-426. [CrossRef]

42. Burrough, P.; McDonnell, R. Spatial Information Systems and Geostatistics. P Burrough R Mcdonnell Princ. Geogr. Inf. Syst. 1998, 333, 1-333.

43. Shepard, D. A two-dimensional interpolation function for irregularly-spaced data. In Proceedings of the 23rd ACM national conference, Las Vegas, NV, USA, 27-29 August 1968; pp. 517-524.

44. Chen, F.-W.; Liu, C.-W. Estimation of the spatial rainfall distribution using inverse distance weighting (IDW) in the middle of Taiwan. Paddy Water Environ. 2012, 10, 209-222. [CrossRef]

45. Jenson, S.K.; Domingue, J.O. Extracting topographic structure from digital elevation data for geographic information system analysis. Photogramm. Eng. Remote Sens. 1988, 54, 1593-1600.

46. Getirana, A.C.; Bonnet, M.-P.; Rotunno Filho, O.C.; Mansur, W.J. Improving hydrological information acquisition from DEM processing in floodplains. Hydrol. Process. Int. J. 2009, 23, 502-514. [CrossRef]

47. Jenson, S.K. Applications of hydrologic information automatically extracted from digital elevation models. Hydrol. Process. 1991, 5, 31-44. [CrossRef]

48. Yaseen, Z.M.; Sulaiman, S.O.; Deo, R.C.; Chau, K.-W. An enhanced extreme learning machine model for river flow forecasting: State-of-the-art, practical applications in water resource engineering area and future research direction. J. Hydrol. 2019, 569, 387-408. [CrossRef]

49. Chuntian, C.; Chau, K.W. Three-person multi-objective conflict decision in reservoir flood control. Eur. J. Oper. Res. 2002, 142, 625-631. [CrossRef]

50. Chau, K. Use of Meta-Heuristic Techniques in Rainfall-Runoff Modelling. Water 2017, 9, 186. [CrossRef]

51. Wu, C.L.; Chau, K.W. Rainfall-runoff modeling using artificial neural network coupled with singular spectrum analysis. J. Hydrol. 2011, 399, 394-409. [CrossRef]

52. Bookhagen, B.; Burbank, D.W. Topography, relief, and TRMM-derived rainfall variations along the Himalaya. Geophys. Res. Lett. 2006. [CrossRef]

53. Bookhagen, B.; Burbank, D.W. Toward a complete Himalayan hydrological budget: Spatiotemporal distribution of snowmelt and rainfall and their impact on river discharge. J. Geophys. Res. 2010. [CrossRef]

54. Mishra, A.; Srinivasan, J. Did a cloud burst occur in Kedarnath during 16 and 17 June 2013? Curr. Sci. 2013, 105, 1351-1352.

55. Bharti, V.; Singh, C.; Ettema, J.; Turkington, T.A.R. Spatiotemporal characteristics of extreme rainfall events over the Northwest Himalaya using satellite data. Int. J. Climatol. 2016, 36, 3949-3962. [CrossRef] 
56. Notti, D.; Giordan, D.; Caló, F.; Pepe, A.; Zucca, F.; Galve, J. Potential and Limitations of Open Satellite Data for Flood Mapping. Remote Sens. 2018, 10, 1673. [CrossRef]

57. Fayne, J.V.; Bolten, J.D.; Doyle, C.S.; Fuhrmann, S.; Rice, M.T.; Houser, P.R.; Lakshmi, V. Flood mapping in the lower Mekong River Basin using daily MODIS observations. Int. J. Remote Sens. 2017, 38, 1737-1757. [CrossRef]

58. Lin, L.; Di, L.; Tang, J.; Yu, E.; Zhang, C.; Rahman, M.; Shrestha, R.; Kang, L. Improvement and Validation of NASA/MODIS NRT Global Flood Mapping. Remote Sens. 2019, 11, 205. [CrossRef]

59. Pandey, R.K.; Crétaux, J.-F.; Bergé-Nguyen, M.; Tiwari, V.M.; Drolon, V.; Papa, F.; Calmant, S. Water level estimation by remote sensing for the 2008 flooding of the Kosi River. Int. J. Remote Sens. 2014, 35, 424-440. [CrossRef]

60. Sahu, S.; Saha, D.; Dayal, S. Sone megafan: A non-Himalayan megafan of craton origin on the southern margin of the middle Ganga Basin, India. Geomorphology 2015, 250, 349-369. [CrossRef]

61. Dixit, A. Kosi embankment breach in Nepal: Need for a paradigm shift in responding to floods. Econ. Political Wkly. 2009, 44, 70-78.

62. Bhatt, C.M.; Rao, G.S.; Manjushree, P.; Bhanumurthy, V. Space based disaster management of 2008 Kosi floods, North Bihar, India. J. Indian Soc. Remote Sens. 2010, 38, 99-108. [CrossRef]

63. Amarnath, G.; Rajah, A. An evaluation of flood inundation mapping from MODIS and ALOS satellites for Pakistan. Geomat. Nat. Hazards Risk 2016, 7, 1526-1537. [CrossRef]

64. Comprehensive Flood Management in India by Central Water Commission (CWC); Information system Organization, CWC: New Delhi, India, 2018; pp. 1-120.

65. Shrestha, D.; Singh, P.; Nakamura, K. Spatiotemporal variation of rainfall over the central Himalayan region revealed by TRMM Precipitation Radar. J. Geophys. Res. Atmos. 2012. [CrossRef]

66. Li, L.; Hong, Y.; Wang, J.; Adler, R.F.; Policelli, F.S.; Habib, S.; Irwn, D.; Korme, T.; Okello, L. Evaluation of the real-time TRMM-based multi-satellite precipitation analysis for an operational flood prediction system in Nzoia Basin, Lake Victoria, Africa. Nat. Hazards 2009, 50, 109-123. [CrossRef]

67. Goel, N.K.; Kurothe, R.S.; Mathur, B.S.; Vogel, R.M. A derived flood frequency distribution for correlated rainfall intensity and duration. J. Hydrol. 2000, 228, 56-67. [CrossRef]

68. Guhathakurta, P.; Sreejith, O.P.; Menon, P.A. Impact of climate change on extreme rainfall events and flood risk in India. J. Earth Syst. Sci. 2011, 120, 359. [CrossRef] 